\title{
Áhrif samkeppni á væntingar, skynjun og tryggð við pjónustutilboð
}

\author{
Pórhallur Örn Guðlaugsson ${ }^{1}$
}

\section{Ágrip}

Viðfangsefni pessarar greinar er að skoða áhrif samkeppni á væntingar, skynjun og tryggð við pjónustutilboð. Stuðst er við gögn úr könnunum meðal nemenda á öðru ári við Háskóla Íslands en par eru pað fyrst og fremst prjár deildir sem búa við mikla samkeppni, lagadeild, viðskipta- og hagfræðideild og verkfræðideild.

Meginniðurstaða rannsóknarinnar er sú að nemendur í samkeppnisdeildunum premur virðast í grundvallaratriðum hafa svipaðar væntingar til pjónustu og nemendur annarra deilda. Umburðarlyndi peirra virðist hins vegar vera minna, sem bendir til pess að aukin samkeppni hafi pau áhrif að kröfur aukast. Niðurstöður benda enn fremur til pess að nemendur samkeppnisdeildanna sýni sinni deildi minni tryggð en nemendur annarra deilda og bendir allt til pess að skólinn sé að færast af seljandamarkaði yfir á kaupendamarkað hvað pær deildir varðar.

\section{Abstract}

This article focuses on the effect of competition on expectations, perception, and loyalty to service offers. Questionnaires were used to gather data from second year students at the University of Iceland, where three faculties in particular face local competition, the faculty of law, the faculty of economics and business administration, and the faculty of engineering.

The main findings of the study indicate that students at the three faculties facing strong local competition report similar expectations as do students at other faculties. However, the results also indicate that they are less tolerant; that the increase competition has lead to higher demands. The results furthermore suggest that the students of the competitive faculties demonstrate less loyalty than do students at other faculties and that in the case of these faculties the University is shifting from a seller's market to a buyer's market.

JEL-flokkun: K2; L4

Lykilhugtök: væntingar, skynjun, tryggd, pjónusta.

\footnotetext{
${ }^{1}$ Pórhallur Örn Guðlaugsson er dósent við viðskipta- og hagfræðideild Háskóla Íslands. Höfundur vill pakka tveimur ónafngreindum ritrýnum fyrir gagnlegar ábendingar í umsögn sinni.
} 


\section{Inngangur}

Pjónustustjórnun er viðfangsefni sem hefur fengið aukið vægi og athygli stjórnenda og fræðimanna síðastliðin 15-20 ár. Ekki er langt síðan fræðimenn fóru að birta niðurstöður rannsókna sem fyrst og fremst fjölluðu um ýmsa áhrifapætti pjónustu (Zeithaml og Bitner, 1996) og enn styttra er síðan rannsóknir á pjónustu opinberra og hálfopinberra fyrirtækja hófust (Laing, 2003). Mörg hefðbundin pjónustufyrirtæki eða -stofnanir hafa verið að próast frá pví að vera pað sem kalla má stjórnsýslulegar skömmtunareiningar, sem höfðu pað hlutverk að útdeila takmörkuðum gæðum til pegna landsins, í pað að verða pjónustueiningar í samkeppni. Sumum pessara fyrirtækja hefur reynst erfitt að fóta sig í samkeppninni og tileinka sér pá breytingu sem felst í pví að fara af sölumarkaði yfir á kaupendamarkað.

Viðfangsefni pessarar greinar er að skoða áhrif samkeppni á væntingar, skynjun og tryggð við pjónustutilboð en rannsóknir benda til pess að aukið val í formi samkeppni hafi pau áhrif að kröfur aukist og tryggð við pjónustutilboð minnki (Zeithaml og Bitner, 2003). Stuðst er við gögn úr könnunum meðal nemenda á öðru ári við Háskóla Íslands en skólinn hefur purft að mæta og bregðast við harðnandi samkeppni innanlands á undanförnum árum.

Í kafla tvö er fjallað um mismunandi skilgreiningar á samkeppni og kynntar eru fjórar nálganir við að skilgreina hana. Pessar skilgreiningar eru samkeppni út frá atvinnugreininni, samkeppni út frá pörfum, samkeppni út frá fjármagni og samkeppni út frá tíma. Dregið er fram að greinar sem við fyrstu sýn virðast ekki eiga í samkeppni geta samt átt í henni. Á pað einkum við pegar skilgreining á samkeppni er víðari en einungis út frá atvinnugreininni sem við á.

Í kafla prjú er fjallað um væntingar. Par er lögð áhersla á að peir sem skipuleggja og stjórna pjónustustarfsemi purfi að hafa haldgóða og djúpa pekkingu á væntingum. Kynntar eru tvær skilgreiningar á væntingum. Annars vegar er kynnt væntingalíkan sem kennt er við Ojasalo (1999) en par er væntingum skipt upp í prjá hluta, óljósar væntingar, ljósar væntingar og sjálfsagðar væntingar. Hins vegar er kynnt líkan sem kennt er við Zeithaml, Berry og Parasuraman (1993) en par er væntingum skipt upp í tvö stig, óskapjónustu og ásættanlega pjónustu.

Í kafla fjögur er fjallað um skynjun og mat á veittri pjónustu. Lögð er áhersla á að um er að ræða skynjun og upplifun pess sem fær pjónustuna sem hefur pað í för með sér að viðskiptavinir geta upplifað sömu frammistöðu ólíkt par sem skynjunin er háð væntingum á hverjum tíma, sem og öðrum ytri og innri áhrifapáttum. Gæði pjónustu er grundvallaratriði í skynjun neytenda og eru í kaflanum kynntar mismunandi nálganir við að skilgreina gæði. Í kaflanum er enn fremur fjallað um SERVQUAL en pað er aðferðafræði sem er byggð á rannsóknum Parasuramans, Zeithamls og Berrys (1985) og margir hafa lagað aðferðina að sínum aðstæðum (Finn og Kayande, 2004).

Í kafla fimm er fjallað um tryggð viðskiptavina við fyrirtæki og tengsl milli fyrirtækis og viðskiptavina. Petta eru lykilhugtök í nútímamarkaðsstarfi en mikilvægi pess að byggja upp grunn tryggra viðskiptavina byggist á pví sjónarmiði að alla jafna sé ódýrara að halda í núverandi viðskiptavini en afla nýrra. Tryggð má 
skilgreina eingöngu út frá hegðun, s.s. endurtekin kaup. Vandamálið við pessa skilgreiningu er fyrst og fremst pað að margir sem endurtaka kaup hjá sama fyrirtæki hafa ekki um annað að velja eða meta skiptikostnaðinn hærri en hugsanlegan ávinning. Önnur leið til að horfa á tryggð er að skilgreina hana sem samspil hegðunar og viðhorfs. Viðhorfið kemur pá pannig fram að viðkomandi líkar við fyrirtækið og pjónustu pess og er tilbúinn að mæla með henni við aðra.

Í kafla sex er gerð grein fyrir rannsókn par sem reynt er að svara peirri spurningu hvort samkeppni hafi áhrif á væntingar, skynjun og tryggð viðskiptavina. Stuðst er við gögn úr viðhorfskönnun meðal annars árs nema við Háskóla Íslands og gengið er út frá pví að nemendur séu viðskiptavinir. Í Háskóla Íslands eru pað fyrst og fremst prjár deildir sem búa við mikla samkeppni en pað eru lagadeild, viðskipta-

og hagfræðideild og verkfræðideild og byggist sú skilgreining á samkeppnisgreiningu sem unnin var í tengslum við stefnumótunarvinnu Háskóla Íslands. Settar eru fram fjórar tilgátur sem tengjast rannsóknarspurningunni, en pær eru:

- T1: Nemendur í samkeppnisdeildum hafa meiri væntingar en nemendur í öðrum deildum.

- $\mathrm{T}_{2}$ : Umburðarlyndi nemenda í samkeppnisdeildum er minna en nemenda í öðrum deildum.

- $\mathrm{T}_{3}$ : Nemendur samkeppnisdeilda eru ekki eins tryggir sínum deildum og nemendur annarra deilda.

- $T_{4}$ : Sterkt samband er á milli heildaránægju og tryggðar.

Rannsóknarkaflanum er skipt í prjá undirkafla. Fyrst er fjallað um aðferðir og upplegg rannsóknarinnar en par er gerð grein fyrir pví um hvers konar gögn er að ræða, hvaða aðferðir voru notaðar við gagnaöflun og hvernig spurningalistinn var uppbyggður. Pá er fjallað um með hvaða hætti unnið er með gögnin og að síðustu er gerð grein fyrir niðurstöðum. Par er leitast við að svara rannsóknarspurningunni og hvort hægt sé að styðja pær tilgátur sem settar eru fram.

Í kafla sjö, sem jafnframt er síðasti kafli greinarinnar, eru niðurstöður dregnar saman. Par kemur m.a. fram að höfundur telur að frekari rannsóknir á pessu sviði séu bæði mikilvægar og áhugaverðar.

\section{Mismunandi skilgreiningar á samkeppni}

Samkeppni er lykilhugtak í viðskiptafræði. Раð hugtak er hins vegar ekki einfalt og ekki eru allir sammála um við hvað er átt pegar talað er um samkeppni. Algengt er að tala um samkeppni sem jákvætt fyrirbæri, að samkeppnin sé af hinu góða, og pví segjast fyrirtæki gjarnan fagna allri samkeppni. Hefðbundið er að skilgreina samkeppni út frá atvinnugreininni sem fyrirtækið starfar í (e. industry point of view) en pá eru pau fyrirtæki í samkeppni sem bjóða upp á sams konar 
vörur eða pjónustu (Kotler, Armstrong, Saunders og Wong, 2001). Út frá pessari skilgreiningu er talað um mismunandi atvinnugreinar eða markaði, s.s. bílamarkaðinn, kvikmyndahúsamarkaðinn, bankamarkaðinn og bensínsölumarkaðinn. Skilgreiningin felur pað í sér að athafnir eins aðila á markaði hafa áhrif á eftirspurn eftir vörum annars aðila á sama markaði. Hér er pví um hefðbundna rekstrarhagfræðilega skilgreiningu á mörkuðum að ræða en par er markaður í aðalatriðum greindur eftir fjölda fyrirtækja á markaði (Ágúst Einarsson, 2005). Samkeppnisaðilar Háskóla Íslands eru samkvæmt pessari skilgreiningu aðrir skólar sem bjóða upp á sams konar menntun, í heild eða að hluta. Innanlands eru t.d. Háskólinn í Reykjavík, Háskólinn á Akureyri, Kennaraháskóli Íslands og Viðskiptaháskólinn á Bifröst virkir samkeppnisaðilar Háskóla Íslands par sem í pessum skólum er að finna nám sem einnig er boðið upp á í Háskóla Íslands. Væntanlegir nemendur geta pví valið milli tveggja skóla og í sumum tilvikum milli priggja. Pví fjölbreyttara sem valið er pví meiri er samkeppnin. Til viðbótar geta nemendur stundað nám annars staðar en hér á landi.

Pessi, í raun prönga, skilgreining á samkeppni og mörkuðum hefur verið gagnrýnd (Levitt, 1960). Hættan sé sú að með slíkri skilgreiningu hætti fyrirtækjum til að skilgreina sig of pröngt og pau horfi fram hjá hugsanlegum tækifærum eða ógnunum sem eru á öðrum mörkuðum. Til að koma til móts við pessa gagnrýni má horfa á samkeppni út frá markaðinum eða pörfinni sem verið er að fullnægja (e. market point of view). Pá er gengið út frá pví að fyrirtæki sem fullnægja sams konar pörfum séu í samkeppni (Andreasen og Kotler, 2003). Pessi skilgreining opnar fyrir pann möguleika að greinar sem við fyrstu sýn virðast alls ekki eiga í samkeppni eiga í raun í henni (Cravens og Piercy, 2003). Út frá pessari skilgreiningu á samkeppni eru samkeppnisaðilar Háskóla Íslands allir peir sem fullnægja sömu eða sams konar pörfum og Háskóli Îslands gerir. Kannanir sýna að væntingar nemenda eru ekki allar pær sömu (Pórhallur Guðlaugsson og Valdimar Sigurðsson, 2005). Sumir leggja mikla áherslu á að fá tækifæri til að vinna að rannsóknum, aðrir leggja meiri áherslu á að vinna raunverkefni fyrir fyrirtæki og stofnanir og enn aðrir sýna háskólanámi áhuga til að efla persónulegan proska.

Samkeppni er einnig oft skilgreind út frá peim peningum sem viðkomandi hefur til umráða. Pá er talað um að barist sé um sömu peningana (Kotler og Keller, 2006) og horft til pess fjármagns sem t.d. fjölskylda hefur til ráðstöfunar. Venjuleg fjölskylda parf að velja á milli pess að endurnýja bílinn, setja nýtt efni á gólfin eða að fara í frí til útlanda. Pannig gætu fyrirtæki, sem samkvæmt hinni hefðbundnu skilgreiningu á samkeppni tilheyra hvert sínum markaði, átt í mikilli samkeppni par sem pau berjast um sömu peningana. Fyrirtæki á gólfefnamarkaði gæti pví hæglega verið í samkeppni við fyrirtæki á ferðamarkaði. Einnig hafa komið fram sjónarmið sem skilgreina samkeppnina út frá tíma (Chang, 2006). Er pá gengið út frá pví að verið sé að keppa um pann tíma sem fólk hefur til ráđstöfunar. Tími sem notaður er í eina athöfn verður ekki notaður í aðra. Petta á einkum við í pjónustu og gerir pað að verkum að gerólíkar pjónustugreinar geta átt í samkeppni. Pannig gæti leikhús átt í samkeppni við háskóladeild par sem nemandinn gæti ákveðið að nota tímann til að undirbúa sig fyrir fyrirlestur morgundagsins í stað pess að fara í leikhús. 
Enn önnur leið til að skilgreina samkeppni er að horfa á hana sem stigbundna (Hollensen, 2003). Hér er í raun um sambland af hefðbundnu skilgreiningunni á samkeppni að ræða annars vegar og svo samkeppni byggða á pörfum hins vegar. Á mynd 1 má sjá að samkeppni fyrir sykurlausa kóladrykki má skipta upp í fimm stig.

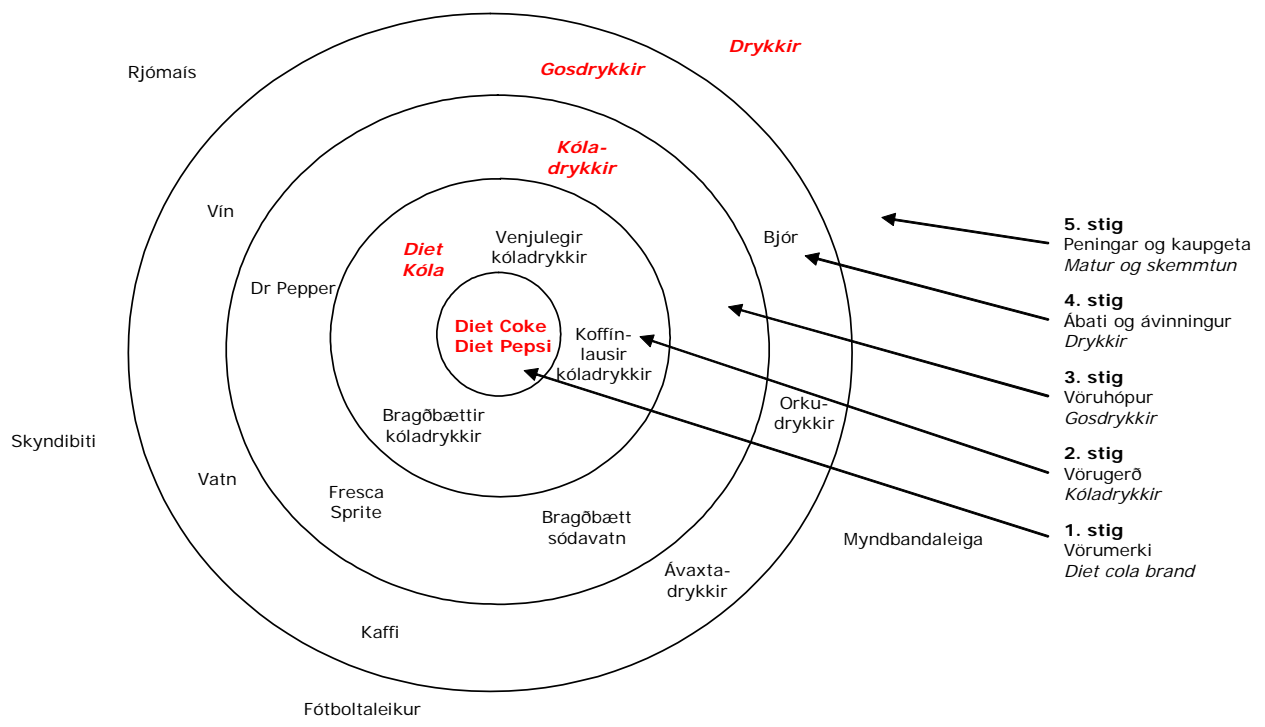

Mynd 1. Mismunandi stig samkeppni (Heimild: Lehmann og Winer, 1991)

Fyrsta stigs skilgreiningin gerir t.d. ráð fyrir að Diet Coke sé í samkeppni við Diet Pepsi. Pá er átt við að pegar sá sem venjulega fær sér Diet Coke fær sér einhvern annan drykk velji hann Diet Pepsi. Ef sá sem venjulega fær sér Diet Coke fær sér bragðbætt sódavatn, t.d. Kristal, pegar hann velur sér annan drykk, má sjá að samkeppni Diet Coke er allt önnur og víðtækari en eingöngu við annan sambærilegan eða eins drykk. Fjórða stigs samkeppni gerir enn fremur ráð fyrir að viðkomandi geti valið milli pess að fá sér gosdrykk eða bjór, orkudrykk, kaffi eða vatn. Ljóst má vera að sá er drekkur vatn drekkur ekki gosdrykk á meðan. Fimmta stigs samkeppnin gerir svo ráð fyrir að viðkomandi purfi að velja á milli pess að fá sér eitthvað að drekka eða nota peningana til að kaupa sér ís, fá sér skyndibita, horfa á fótboltaleik eða leigja sér myndband.

Á undanförnum misserum hefur nokkuð verið rætt um samkeppni milli háskóla. Рað er pá gjarnan gert með jákvæðum formerkjum, p.e. að með tilkomu samkeppninnar batni starf skólanna á pann hátt að samkeppnin virki sem hvati til að standa sig betur en áður. Eins og að framan greinir hefur samkeppni á sér margar hliðar. Pegar rætt er um samkeppni á skólamarkaði parf að vera ljóst við hvað er átt. Snýst samkeppni fyrst og fremst um að laða að sér sem flesta nemendur og fá greitt fyrir sem flestar „preyttar“ einingar eða snýst hún um að laða að sér hæfa kennara eða að ná athygli stjórnvalda? Í peirri rannsókn sem fjallað er um í tengslum við pessa grein er fyrst og fremst horft á samkeppni um nemendur. Gengið er út frá pví að pví fleiri kostir sem í boði eru fyrir nemendur pví meiri sé samkeppnin. Deildir Háskóla Íslands búa við mismunandi aðstöðu hvað petta varðar og eru pað fyrst og 
fremst lagadeild, verkfræðideild og viðskipta- og hagfræðideild sem eiga í hvað mestri samkeppni um nemendur innanlands. Áhrif samkeppninnar eru margvísleg og er í greininni lagt mat á pau áhrif sem samkeppnin hefur á væntingar nemenda til veittrar pjónustu, skynjun peirra á frammistöðu og tryggð nemenda við skólann/deildina sem og til pjónustunnar sem peir fá.

\section{Væntingar}

Flestir hafa einhverja pekkingu á væntingum og eðli peirra. Раð er pó nauðsynlegt að peir sem skipuleggja pjónustu hafi góða og haldbæra pekkingu og skilning á peim (Zeithaml og Bitner, 2003). Pannig er bent á að pegar Malcolm Baldrige National gæðaverðlaunin eru veitt er sérstaklega kannað hve vel hugsanlegir vinningshafar pekkja væntingar viðskiptavina sinna (Walker og Baker, 2000). Reglulegt mat á próun væntinga virðist pví forsenda fyrir árangri hvað varðar pað að veita góða pjónustu. Í pessu sambandi er mikilvægt að horfa til pess að mat á væntingum getur verið margs konar. Pannig getur mat á mikilvægi verið um leið mat á væntingum (sjá Zeithaml og Bitner, 2003; Hayes, 1998; Lovelock og Writz, 2001) en peirri aðferð er beitt við mat á væntingum í peirri rannsókn sem hér er til umfjöllunar.

Pegar skilgreina á væntingar er mikilvægt að hafa í huga að væntingar eru ekki eitthvað eitt heldur samsafn margra tilfinningalegra atriða (Grönroos, 2000). Í rannsókn Ojasalos (2001) er væntingum skipt upp í prjá hluta, óljósar væntingar (e. fuzzy expectations), ljósar væntingar (e. explicit expectations) og sjálfsagðar væntingar (e. implicit expectations). Prátt fyrir að rannsóknin hafi verið bundin við sérfræðipjónustu kemur í ljós að pessi skipting virðist eiga ágætlega við pjónustu almennt (Grönroos, 2000). Með óljósum væntingum er átt við pað pegar viðskiptavinurinn býst við að pjónustuaðilinn leysi vandamálið, án pess pó að gera sér grein fyrir hvað til parf svo аð раð gerist. Ljósar væntingar eru hins vegar skýrar í huga viðskiptavinarins og geta pessar væntingar ýmist verið raunhæfar eða óraunhæfar, sanngjarnar eða ósanngjarnar. Sjálfsagðar væntingar eru pær væntingar sem viðskiptavinurinn gerir ráð fyrir að fá uppfylltar án pess að hugsa um pað sérstaklega eða að purfa að fara fram á pað. Petta líkan Ojasalos má sjá á mynd 2. 


\section{Væntingalíkan Ojasalos}

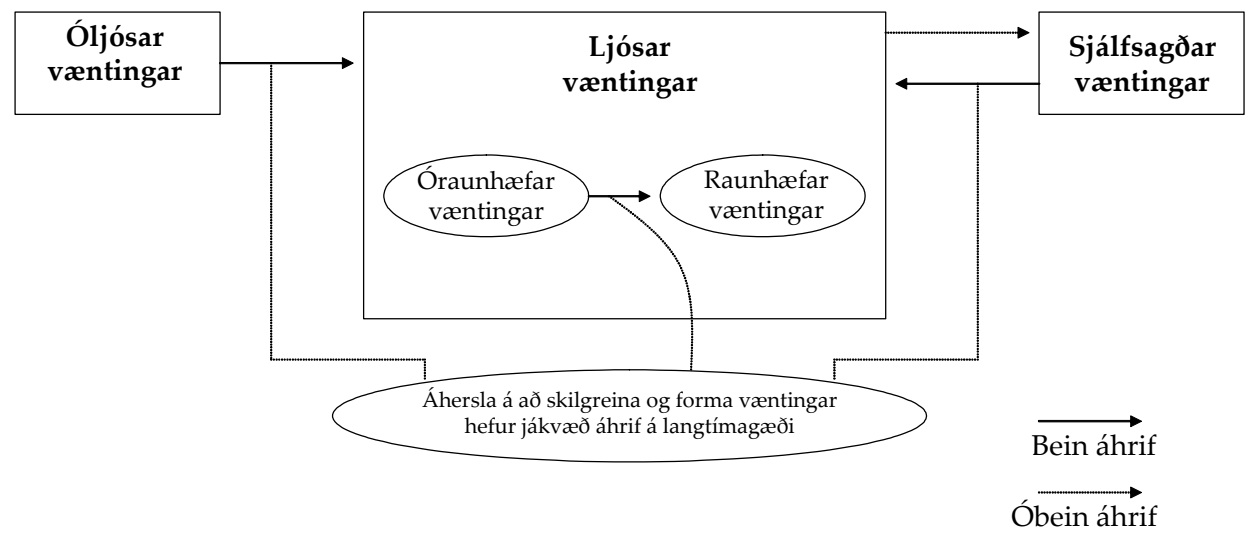

Mynd 2. Væntingalíkan Ojasalos (Heimild: Ojasalo, 2001)

Eins og sjá má á mynd 2 er ákveðið samband milli óljósra væntinga, ljósra væntinga og sjálfsagðra væntinga. Óljósar væntingar leiða af sér ljósar væntingar, sem aftur leiða af sér sjálfsagðar væntingar. Óbeint samband er á milli sjálfsagðra væntinga og ljósra væntinga. Í líkaninu er lögð áhersla á að allar pessar væntingar purfi að skilgreina og forma svo að gæði verði tryggð til lengri tíma litið.

Eitt algengasta líkan væntinga er byggt á rannsóknum Zeithamls, Berrys og Parasuramans (1993) og prátt fyrir að ýmis önnur líkön hafi komið fram (sjá t.d. Grönroos, 1988) byggja flestir höfundar á pessari rannsókn í umfjöllun sinni um væntingar (sjá t.d. Bruhn og Georgi, 2006; Fisk, Grove og John, 2000; Palmer, 2001, Lovelock og Writz, 2004 og Zeithaml, Bitner og Gremler, 2006). Par er væntingum skipt í tvo hluta, óskapjónustu, (e. desired services) og ásættanlega pjónustu (e. adequate services). Óskapjónusta er sú pjónusta sem viðskiptavinurinn vonast til að fá, p.e. ósk um frammistöðu pess er veitir pjónustuna. Ásættanleg pjónusta er sú pjónusta sem viðskiptavinurinn telur ásættanlega og fullnægjandi. Fari frammistaða pess sem pjónustuna veitir niður fyrir pessi mörk finnst viðskiptavininum að hann fái ekki fullnægjandi pjónustu. Nokkuð hefur verið rannsakað hvort viðskiptavinir hafi sömu væntingar til allra aðila í sömu grein (Woodruff, Cadotte og Jenkins, 1987). Flest bendir til að svo sé ekki, p.e. að væntingar séu pær sömu í ákveðnum hluta greinarinnar en ólíkar pegar greinin er skoðuð í heild sinni. Líklegt er að viðskiptavinir hafi aðrar væntingar til almenningssamgangna en pjónustu leigubifreiða svo að dæmi sé tekið (sjá nánar Higgins, 2002; Rotondaro, 2002 og Farsad og Elshennawy, 1989).

Bilið á milli óskapjónustu og ásættanlegrar pjónustu er kallað umburðarlyndi. Sá sem fær tiltekna pjónustu sættir sig við einhver frávik frá óskapjónustu. Á mynd 3 má sjá sambandið milli óskapjónustu, ásættanlegrar pjónustu og umburðarlyndis ásamt áhrifapáttum sem ýmist hafa áhrif á óskapjónustu, ásættanlega pjónustu eða bæði stigin. 


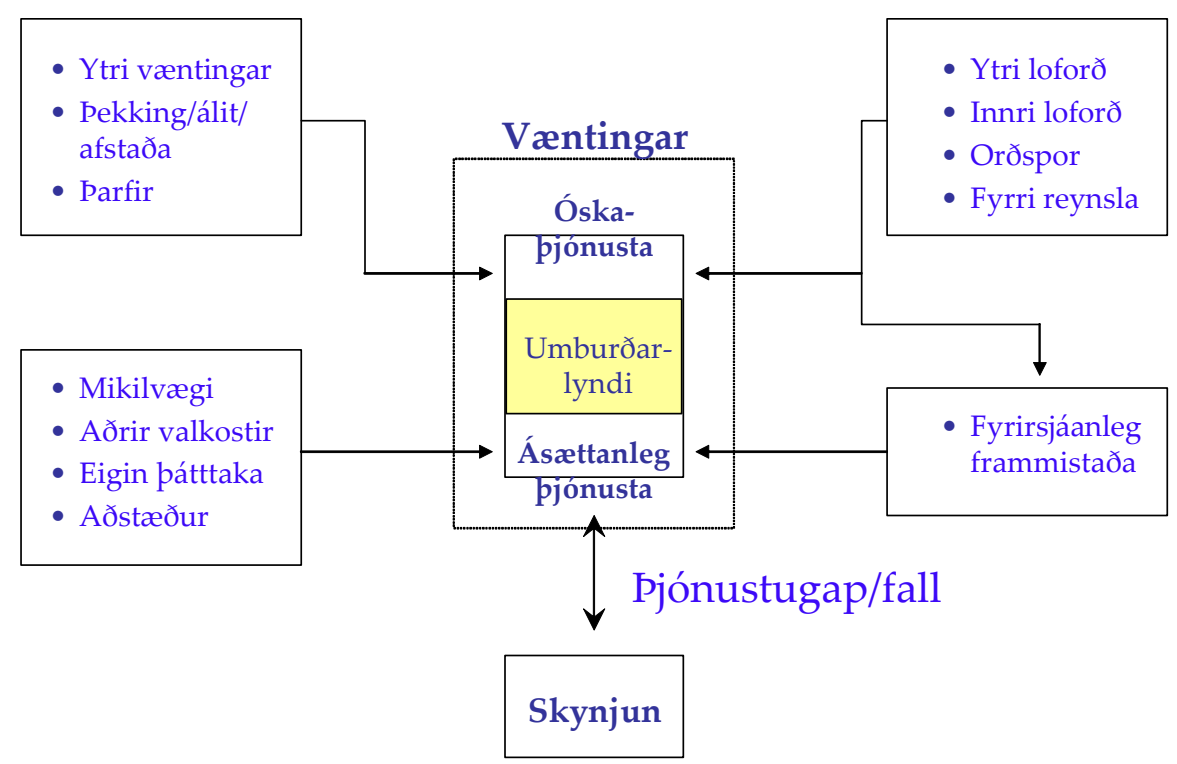

Mynd 3. Væntingalíkan Zeithamls, Berrys og Parasuramans (Heimild: Zeithaml og Bitner, 2003)

Eins og sjá má á mynd 3 hefur umburðarlyndi efri og neðri mörk. Frammistaða sem lendir innan pessa marka vekur ekki neina sérstaka eftirtekt, p.e. allt er eins og við er að búast og hægt er að ætlast til. Petta bil hefur pví stundum verið kallað áhugaleysisbil (Heskett, Sasser og Schlesinger, 1997). Frammistaða sem lendir utan pessa marka framkallar hins vegar viðbrögð. Ef pjónustan er mun betri en við búumst við verðum við ánægð og mælum hugsanlega með pjónustunni. Ef hún er verri en við búumst við og lendir neðan marka ásættanlegrar pjónustu verðum við óánægð, viljum kvarta og hallmælum jafnvel pjónustunni.

Óskapjónustan er, eins og áður segir, efri mörk væntinganna. Petta er pað stig pjónustu sem viðskiptavinurinn vonast til að fá, í raun pað sem að hann vonar að komi út úr framkvæmdinni. Óskapjónusta er pví sambland af pví sem viðskiptavinurinn telur að gæti orðið niðurstaðan annars vegar og svo hver hún ætti að vera hins vegar (Grönroos, 1982 og Brown og Swartz 1989). Sem dæmi um óskapjónustu mætti taka háskólastúdent sem er að útskrifast og leitar til atvinnumiðlunar í leit sinni að starfi að námi loknu. Óskapjónustan væri sú að atvinnumiðlunin útvegaði honum strax starf við hæfi par sem launin væru góð, sem og önnur fríðindi. Stúdentinn áttar sig pó á pví að ekki er víst að nákvæmlega petta gerist, bæði vegna pess að aðstæður geta verið með peim hætti að erfitt er að útvega góða vinnu en einnig vegna pess að ekki er víst að vinnumiðlunin sé einmitt í sambandi við pað fyrirtæki sem stúdentinn hefði mestan áhuga á að starfa hjá. Stúdentinn gæti pví sætt sig við eitthvað minna en sem óskapjónustunni nemur, s.s. heldur lægri laun eða starf sem er ekki alveg á pví sviði sem hann hefur menntað sig á. Pessi neðri mörk eru kölluð ásættanleg pjónusta, p.e. neðri mörk frammistöðu (Woodruff, Cadotte og Jenkins, 1987). Á milli óskapjónustu og ásættanlegrar pjónustu er рað sem kallað er umburðarlyndi (Parasuraman, Berry og Zeithaml, 1991a og Parasuraman, Berry og Zeithaml, 1991b). Ef frammistaðan fer upp fyrir efri 
mörk, p.e. upp í óskapjónustu, verður viðskiptavinurinn mjög ánægður og er tilbúinn að mæla með pjónustunni. Ef frammistaðan fer niður fyrir neðri mörk umburðarlyndis, p.e. niður fyrir ásættanlega pjónustu, verður viðskiptavinurinn óánægður og líklegur til að kvarta eða hallmæla pjónustunni við priðja aðila (Berry, Parasuraman og Zeithaml, 1993). Rannsóknir sýna að umburðarlyndið er hreyfanlegt par sem ásættanleg pjónusta breytist mun oftar og meira en óskapjónusta (sjá Zeithaml, Bitner og Gremler, 2006 og Doole, Lancaster og Lowe, 2005). Peir sem nota tiltekna pjónustu hafa mismikið umburðarlyndi gagnvart sömu frammistöðu. Margir pættir hafa áhrif á væntingarnar, s.s. persónulegar parfir, álit og afstaða, sem hefur fyrst og fremst áhrif á óskapjónustu. Mikilvægi, aðrir valkostir, eigin pátttaka og aðstæður hafa hins vegar fyrst og fremst áhrif á ásættanlega pjónustu. Einnig hafa innri og ytri loforð, orðspor og fyrri reynsla áhrif á óskapjónustu en einnig á fyrirsjáanlega frammistöðu, sem aftur hefur áhrif á ásættanlega pjónustu (sjá nánar á mynd 3).

Í mati á gæðum pjónustu er mikilvægt að leggja mat á væntingar eða mikilvægi um leið og lagt er mat á frammistöðu (Parasuraman, Zeithaml og Berry, 1994 og Falzon, 1988). Mælitækið sem stuðst er við í pessu mati gengur undir nafninu SERVQUAL og prátt fyrir nokkra gagnrýni á aðferðafræðina (sjá t.d. Cronin og Taylor, 1992 og Teas, 1993) hefur höfundum líkansins tekist að sýna fram á mikilvægi pess að meta samtímis væntingar og frammistöðu, sérstaklega pegar horft er til notagildis niðurstaðna fyrir stjórnendur. Gagnrýnin liggur fyrst og fremst í pví að erfitt sé að leggja mat á væntingar og pví sé slíkt mat í raun mat á frammistöðu fremur en væntingum. Til að vinna bug á pessu vandamáli hafa margir farið pá leið að nota mikilvægi sem mælikvarða á væntingar (sjá t.d. Hayes, 1998, Williams, 2002 og Christensen, 2004) og setja niðurstöðurnar fram á svokölluðu mikilvægis- og frammistöðukorti (sjá Zeithaml og Bitner, 1996). Раð аð skynsamlegt sé að nota mikilvægi pjónustupátta sem mælikvarða á væntingar til frammistöðu í peim páttum fékkst einnig staðfest í forkönnun höfundar meðal nemenda í viðskipta- og hagfræðideild Háskóla Íslands, en par kom í ljós að mjög sterkt samband var á milli mats á væntingum annars vegar og mats á mikilvægi hins vegar $(\mathrm{r}(26)=0,963$; $\mathrm{P}<0,001$ ). Eins og sjá má er sambandið mjög sterkt (sjá Cohen, 1988) og pví er farin sú leið í peirri rannsókn sem hér er til umfjöllunar að nota mikilvægi sem mælikvarða á væntingar, enda eiga svarendur alla jafna mun auðveldara með að segja til um hve mikilvægt tiltekið atriði er að peirra mati en að segja til um væntingar sínar í tengslum við pað (sjá Cronin og Taylor, 1992 og Boulding, Kalra, Staelin og Zeithaml, 1993).

\section{Skynjun}

Skynjunarhugtakið (e. perception) pegar pjónusta er annars vegar er í raun mat viðskiptavinar á gæðum veittrar pjónustu (Anreassen, 1994). Hér er lögð áhersla á að um skynjun er að ræða og upplifun pess sem fær pjónustuna. Pannig geta mismunandi viðskiptavinir (eða sami viðskiptavinur í mismunandi skipti) upplifað sömu frammistöðu með mismunandi hætti par sem skynjunin er háð væntingum á hverjum tíma, sem og öðrum ytri og innri áhrifapáttum (sjá Zeithaml, Bitner og 
Gremler, 2006). Gæði pjónustu er grundvallaratriði í skynjun neytenda (Solomon, Bamossy og Askegaard, 2002). Ef tilboðið er nánast eingöngu pjónusta skiptir mat viðskiptavinar á gæðum hennar meginmáli. Jafnvel par sem tilboðið er sambland ápreifanlegrar vöru og pjónustu geta pjónustugæði skipt meginmáli við heildarmat á pví sem viðskiptavinurinn fær í hendur (sjá t.d. Zeithaml og Bitner, 2003).

Segja má að formlegt mat á pjónustugæðum megi rekja til rannsókna Olivers (1977) annars vegar og Olshavskys og Millers (1972) hins vegar. Í báðum pessum rannsóknum gætir mikilla áhrifa frá rannsóknum Carlsmiths og Aronsons frá 1963 (sjá Kasper, Helsdingen og Gabbott, 2006, bls. 183). Út frá pessu má sjá að tiltölulega nýlega er farið að fjalla pjónustugæði og mat á peim í tengslum við stjórnun. Enn fremur kemur vel fram í framangreindum heimildum að aðferðir við að meta pjónustugæði hafa próast út frá öðrum greinum, s.s. framleiðslustjórnun og almennri gæðastjórnun. Mikilvægt er pví fyrir pá sem ætla að meta pjónustugæði að pekkja vel til gæðamála almennt. Garvin (1988) kynnti fimm mismunandi leiðir til að öðlast skilning á gæðum. Pessar fimm leiðir til að meta gæði eru:

1. gæði byggð á yfirburðaframmistöðu (e. transcendent-based),

2. gæði byggð á eiginleikum (e. attribute-based),

3. gæði byggð á afstöðu notandans (e. user-based),

4. gæði út frá framleiðslu (e. manufacturing-based)

5. gæði byggð á virði (e. value-based).

Eins og sjá má er hér um afar ólíkar skilgreiningar að ræða. Skilgreiningar 1, 3 og 5 byggjast á mati viðskiptavina en skilgreiningar 2 og 4 á framleiðslu. Eins og áður hefur komið fram ganga mælingar á pjónustugæðum út á pað að meta skynjun viðskiptavina á veittri pjónustu og tengjast pví sterkt skilgreiningum 1, 3 og 5 .

Grönroos (1988) setti fram skilgreiningu um hvernig viðskiptavinir mætu gæði pjónustu. Lagði hann mikla áherslu á að skynjun á gæðum pjónustu tengdust mikið eiginleikum pjónustunnar, p.e. að hún sé að miklu leyti óápreifanleg, sé ferill fremur en hlutur, eigi sér stað í rauntíma og að viðskiptavinurinn gegni gjarnan veigamiklu hlutverki. Enn fremur benti Grönroos á athyglisvert sjónarmið, p.e. að ekki skiptir eingöngu máli HVAĐA pjónustu maður fær heldur einnig HVERNIG hún er framkvæmd. Í pessu sambandi talar hann um tvær gæðavíddir, tæknileg gæði annars vegar og gæði ferilsins hins vegar. Tæknileg gæði eru í raun gæði útkomunnar, p.e. HVAĐA pjónusta er veitt. Gæði ferilsins standa fyrir HVERNIG pjónustan er innt af hendi og er pá horft til allra peirra samskipta sem eiga sér stað á meðan pjónustan er veitt.

Parasuraman, Zeithaml og Berry (1985) lögðu grunninn að aðferð til að meta gæði pjónustu sem kölluð hefur verið SERVQUAL. Pessi aðferð var nánar útfærð í rannsókn Parasuramans, Zeithamls og Berrys (1988) og margir hafa lagað aðferðina að sínum aðstæðum (Finn og Kayande, 2004). Síðan 1985 hafa höfundar SERVQUAL 
próað aðferðina áfram í peim tilgangi að betrumbæta hana en með pví að nota niðurstöður páttagreiningar var gert ráð fyrir 10 víddum í upphaflega líkaninu:

- Ápreifanleiki (e. tangibles). Aðstaða, tæki, starfsfólk og umgjörð.

- Áreiðanleiki (e. reliability). Hæfnin til að veita pjónustuna með réttum hætti.

- Svörun/viðbrögð (e. responsiveness). Viljinn til að aðstoða viðskiptavini.

- Hæfni (e. competence). Hvort til staðar er rétt pekking og hæfni til að veita pjónustuna.

- Kurteisi (e. courtesy). Kurteisi, virðing, umhyggja og vingjarnlegt viðmót.

- Trúverðugleiki (e. credibility). Traust, trúverðugleiki og heiðarleiki.

- Öryggi (e. security). Laus við áhættu og ógn.

- Aðgengi (e. access). Möguleikinn á að hafa samband.

- Samskipti (e. communication). Hvort viðskiptavinum er haldið upplýstum.

- Skilningur (e. understanding). Viðleitni til að skilja parfir og óskir viðskiptavina.

Pessum tíu víddum hefur verið fækkað í fimm (sjá Zeithaml, Bitner og Gremler, 2006) og hefur pessi aðferð verið leiðandi í rannsóknum á pjónustugæðum. Víddirnar ganga gjarnan undir nafninu RATER-víddirnar (sjá Kasper, Helsdingen og Gabbot, 2006) en pær eru:

- Áreiðanleiki (e. reliability). Hæfnin til að framkvæma pá pjónustu sem lofað var á traustan og réttan hátt.

- Trúverðugleiki (e. assurance). Pekking og framkoma starfsfólks ásamt getu fyrirtækisins og starfsfólks pess til að stuðla að trausti og trúverðugleika.

- Ápreifanleiki (e. tangibles). Umgjörð pjónustunnar, s.s. aðstaða, búnaður og útlit starfsfólks.

- Hluttekning (e. empathy). Sú umhyggja sem fyrirtækið sýnir viðskiptavinum sínum.

- Svörun og viðbrögð (e. responsiveness). Viljinn til að hjálpa viðskiptavinunum og veita peim fullnægjandi pjónustu. 
Á mynd 4 má sjá tengsl gæðavíddanna við pjónustugæði og með hvaða hætti pjónustugæði tengjast ánægju viðskiptavina. Enda pótt hugtökin pjónustugæði og ánægja viðskiptavina hafi fengið aukna athygli stjórnenda og rannsakenda síðastliðin ár virðist vera tilhneiging til að leggja að jöfnu ánægju og gæði, p.e. að petta tvennt sé í raun eitt og hið sama. Ánægja er mun víðtækara hugtak en pjónustugæði en pau grundvallast fyrst og fremst á tilteknum pjónustuvíddum eða eiginleikum. Pjónustugæði eru pví veigamikill áhrifapáttur á ánægju viðskiptavina en aðrir pættir hafa einnig áhrif, s.s. persónulegir pættir, aðstæður, verð og vörugæði (Parasuraman Berry og Zeithaml, 1994). Á mynd 4 má sjá að pjónustugæði eru aðeins einn af fleiri páttum sem eiga hver sinn pátt í heildaránægju viðskiptavina. Með gæðum pjónustu er pví aðeins hægt útskýra hluta heildaránægjunnar.

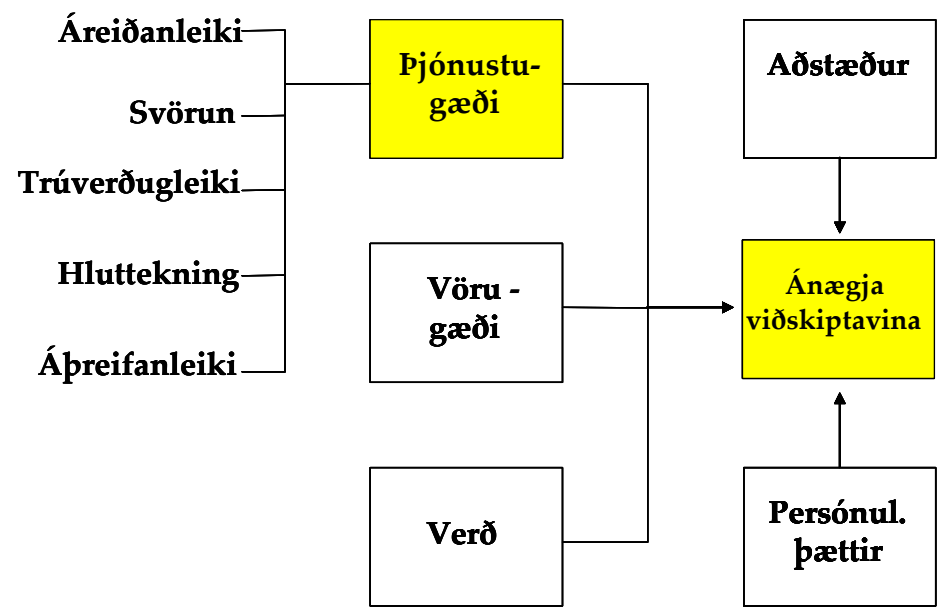

Mynd 4. Áhrifapættir á ánægju viðskiptavina (Heimild: Zeithaml og Bitner, 1996)

Pekking á páttunum, p.e. öðrum páttum en pjónustugæðum, skiptir pví miklu máli pegar verið er að leggja mat á afstöðu viðskiptavina til pjónustu par sem aldrei verður hægt að skýra út nema hluta af heildaránægju viðskiptavina með pjónustugæðum eingöngu. Í rannsóknum á tengslum pjónustugæða við heildaránægju er pví gengið út frá að pjónustugæði stuðli að ánægju viðskiptavina en taka purfi tillit til annarra pátta pegar leggja á mat á heildaránægju (Zeithaml, Bitner og Gremler, 2006)

Í sinni einföldustu mynd skilgreinir SERVQUAL gæði sem muninn á væntingum viðskiptavina annars vegar og skynjun á veittri pjónustu hins vegar. Með aðferðinni er lögð áhersla á að mæla skynjun, sem og væntingar eða mikilvægi. Fyrir hverja vídd er pá hægt að meta pjónustugæðin samkvæmt eftirfarandi formúlu:

$$
\begin{gathered}
\text { Skynjun }- \text { Væntingar }=\text { Pjónustugæði } \\
S-V=P
\end{gathered}
$$


Nokkuð skiptar skoðanir eru á túlkun niðurstaðna (sjá Kasper, Helsdingen og Gabbot, 2006). Sé mælt á fimm stiga kvarða gæti ein túlkun verið sú að mestu gæðin séu pegar útkoman er 4, p.e. 5 í frammistöðumælingunni og 1 í væntinga/mikilvægismælingunni. Með sömu skilgreiningu væru minnstu gæðin -4, p.e. 1 í frammistöðumælingunni og 5 í mikilvægismælingunni. Fyrra dæmið bendir til pess að um svokallað yfirskot sé að ræða en pá er frammistaðan mjög góð í atriði sem skiptir litlu máli, sem tæplega er eftirsóknarverð niðurstaða. Seinna dæmið ber með sér veikleika en pá er frammistaðan mjög slök í atriði sem skiptir miklu máli. Í pessari grein er fyrst og fremst horft á mismuninn, p.e. bilið milli væntinga/mikilvægis og skynjunar. Venjulega er hér um neikvætt gildi að ræða, p.e. væntingarnar fá fleiri stig en frammistaðan, en stundum er gildið jákvætt. Pví meira sem bilið er, pví meiri athygli á viðkomandi atriði að fá pegar kemur að forgangsröðun aðgerða.

Margir aðrir hafa horft á pjónustugæði sem samspil nokkurra vídda eða aðgerða. Pannig tala Brady og Cronin (2001) um prjár víddir, gæði útkomunnar, gæði pjónustuferilsins og gæði hlutlægra pátta. Bitner (1993 kynnti enn fremur til sögunnar pjónustutilvist (e. evidence of service) en par er talað um fólk (e. people), ferla (e. process) og umgjörð (e. physical evidence).

\section{$5 \quad$ Tryggð}

Hugtökin tryggð (e. loyalty) og tengsl við viðskiptavini (e. customer relationships) eru lykilhugtök í nútímamarkaðsstarfi (Zinkham, 2001). Mikilvægi pess að byggja upp grunn af tryggum viðskiptavinum byggist á pví sjónarmiði að alla jafna sé ódýrara að halda í pá viðskiptavini sem fyrirtækið hefur pegar en að afla nýrra (Kotler, Armstrong, Saunders og Wong, 2001 og Zeithaml, Parasuraman og Berry, 1990). Hugtakið tryggð í markaðsfræðum er nátengt hugtakinu tengsl (e. relationship) í sömu fræðum (Moller og Halinen, 2000). Viðskiptavinur sem fær góða pjónustu og er ánægður með hana er líklegri til að sýna meiri tryggð við pá pjónustu, ýmist með pví að kaupa pjónustuna aftur eða mæla með henni við aðra (Boulding, Kalra, Staelin og Zeithaml, 1993). Einnig kemur í ljós að tryggð og ánægja viðskiptavina getur aukist ef rétt er brugðist við mistökum sem átt hafa sér stað í pjónustuframkvæmd (McCollough, Berry og Yadav, 2000, Zeithaml, Berry og Parasuraman, 1993 og Grönroos, 1990).

Nokkuð hefur verið rannsakað með hvaða hætti á að byggja upp tryggan viðskiptavinahóp (sjá t.d. Christopher, Payne og Ballantyne, 1991, Gummesson, 2002 og Griffin, 1997) en ekki síður af hverju viðskiptavinir mynda tryggð við tiltekið fyrirtæki, vöru eða vörumerki (Gwinner, Gremler og Bitner, 1988). Horfa má á tryggð eingöngu út frá hegðun, s.s. sem endurtekin kaup. Vandamálið við pessa nálgun er fyrst og fremst раð аð margir sem endurtaka kaup gera pað vegna pess að peir hafa engan annan kost. Petta á t.d. við í almenningssamgöngum en ætla má að nemendur noti almenningsfarartæki að einhverju leyti vegna pess að peir hafa ekki um annað að velja. Einnig parf að taka til greina skiptikostnað en pá metur viðskiptavinurinn pá fyrirhöfn, og hugsanlega kostnað, við að skipta um pjónustuaðila sem meiri en ávinninginn (Kotler, Wong, Saunders og Armstrong, 2005). Petta á t.d. við um 
bankapjónustu á einstaklingsmarkaði, sem og sérfræðipjónustu á fyrirtækjamarkaði. Pjónustufallið parf að vera mjög mikið til að réttlæta skiptikostnaðinn. Hin leiðin er að horfa á tryggð sem sambland af hegðun, viðskiptavinurinn kaupir aftur, og viðhorfi, viðskiptavininum líkar við fyrirtækið og er tilbúinn að mæla með pví við aðra. Viðskiptavinir geta verið mjög jákvæðir gagnvart tiltekinni pjónustu pótt peir geti ekki nýtt sér hana af einhverjum ástæðum. Einnig má benda á sjónarmið sem ganga út á að stundum sé ekki æskilegt að viðskiptavinir komi aftur og aftur. Pannig er ekki æskilegt að nemandi komi aftur og aftur í sama námskeiðið eða skjólstæðingur félagslegrar pjónustu sé upp á hana kominn um alla eilífð. Í báðum pessum tilvikum er pó mikilvægt að viðkomandi hafi jákvætt viðhorf til pjónustunnar og sé tilbúinn að mæla með henni við aðra eins og við á.

\section{6 Áhrif samkeppni á væntingar, skynjun og tryggð}

Í rannsókninni er unnið út frá rannsóknarspurningunni: „Hefur samkeppni einhver áhrif á væntingar, skynjun og tryggð viðskiptavina?" Miklar breytingar hafa átt sér stað í háskólaumhverfinu hér á landi síðastliðin ár. Breytingarnar felast fyrst og fremst í pví að tekið hafa til starfa háskólar sem veita Háskóla Íslands samkeppni.

Eins og áður segir eru pað fyrst og fremst prjár deildir í Háskóla Íslands sem búa við mikla samkeppni, en pað eru lagadeild, viðskipta- og hagfræðideild og verkfræðideild. Pessi fullyrðing byggist á samkeppnisgreiningu sem gerð var í tengslum við stefnumótunarvinnu Háskóla Íslands en par kemur fram að pað séu einkum pessar deildir sem búa við samkeppni um nemendur hér á landi. Til að meta niðurstöður eru pessar deildir teknar saman í einn hóp, kallaðar samkeppnisdeildir, og aðrar deildir eru settar saman í viðmiðunarhóp, kallaðar aðrar deildir.

Í tengslum við rannsóknarspurninguna og pá fræðilegu umfjöllun sem finna má framar í greininni eru settar fram eftirfarandi tilgátur:

- T1: Nemendur í samkeppnisdeildunum hafa meiri væntingar til pjónustupátta en nemendur í öðrum deildum. Gengið er út frá pví að aukið val, og par með samkeppni, hafi pau áhrif á væntingar nemenda að peir geri meiri kröfur en nemendur í öðrum deildum gera.

- $T_{2}$ : Umburðarlyndi nemenda í samkeppnisdeildum er minna en nemenda í öðrum deildum. Gengið er út frá pví að aukið val, og par með samkeppni, hafi pau áhrif að par sem samkeppni er til staðar sé pjónustan dæmd harðar en annars staðar og pað hefur pau áhrif að pjónustugapið/-bilið stækkar.

- T3: Nemendur samkeppnisdeilda eru ekki eins tryggir skólanum og nemendur annarra deilda. Hér er stuðst við tvær spurningar sem mæla tryggð. Pessar spurningar fjalla um líkur á pví að nemendurnir mæli með pjónustunni annars vegar og líkur á pví að peir velji hana aftur hins vegar. Gengið er út frá pví að nemendur samkeppnisdeilda sýni skólanum ekki eins mikla tryggð og nemendur annarra deilda. 
- T4: Sterkt samband er á milli heildaránægju og tryggðar. Gengið er út frá pví að pví ánægðari sem viðkomandi er með frammistöðuna, pví tryggari sé hann skólanum. Hér er tryggð metin sem vilji viðkomandi til að mæla með pjónustunni við aðra og velja hana aftur ef hann væri í peim sporum að hefja nám.

Rannsóknarkaflanum er skipt í prjá undirkafla. Fyrst er fjallað um aðferðir og upplegg rannsóknarinnar en par er gerð grein fyrir pví hvers konar gögn voru notuð, hvaða aðferðir voru notaðar við gagnaöflunina og hvernig spurningalistinn var uppbyggður. Pá er fjallað um með hvaða hætti unnið var úr gögnunum og að síðustu er gerð grein fyrir niðurstöðum. Par er leitast við að svara rannsóknarspurningunni og hvort hægt sé að styðja pær fjórar tilgátur sem settar eru fram.

\subsection{Aðferð og upplegg rannsóknarinnar}

Gögnin byggjast á tveimur sjálfstæðum könnunum meðal annars árs nema við Háskóla Íslands árið 2005 og 2006. Í báðum tilvikum fóru kannanirnar fram í febrúar og í báđum tilvikum var svörun ríflega 40\%. Í fyrri könnuninni fékkst 461 svar en 538 svör úr peirri seinni. Heildarfjöldi svara er 999, 300 frá nemendum samkeppnisdeilda og 699 frá nemendum annarra deilda. Framkvæmd var eins í báðum tilvikum og sýna niðurstöður að úrtakið endurspeglar vel kynskiptingu í skólanum, sem og skiptingu á fjölda nemenda milli deilda.

Stuðst var við próaða útgáfu af SERVQUAL en spurningalistinn var settur upp í vefforritinu WebSurveyor. Sendur var póstur á alla nemendur á öðru ári og tvisvar var send út áminning til peirra er áttu eftir að svara. Í báðum tilvikum tók svörun kipp og bendir pað til pess að með aðferð sem pessari, p.e. netkönnun, svari peir sem á annað borð ætla að gera pað, strax eða fljótlega eftir að peir lesa tölvupóstinn.

Spurningalistinn var fjórskiptur. Í fyrsta hluta voru nemendur beðnir um að taka afstöðu til sextán fullyrðinga sem standa fyrir tiltekin atriði í pjónustunni eða umgjörð hennar og var stuðst við fimm stiga Likert-kvarða par sem 1 stóð fyrir mjög ósammála og 5 fyrir mjög sammála. Eftirfarandi fullyrðingar voru settar fram:

1. Við skólann er öflugt félagslíf.

2. I I náminu fæ ég tækifæri til að vinna við rannsóknir.

3. Í náminu fæ ég tækifæri til að vinna verkefni fyrir fyrirtæki og stofnanir.

4. Deildin er búin tækjabúnaði sem uppfyllir kröfur nútímans.

5. Húsnæði uppfyllir vel parfir mínar.

6. Framkoma starfsfólks (kennarar og aðrir) ber vott um fagmennsku.

7. Gögn um pjónustu deildarinnar, s.s. bæklingar, kennslugögn og heimasíða, eru aðlaðandi í útliti. 
8. Ef kennari hefur lofað að gera eitthvað fyrir ákveðinn tíma, pá er staðið við раð.

9. Pjónustan sem deildin veitir er skilvirk.

10. Ég ber traust til starfsfólks deildarinnar.

11. Starfsfólk deildarinnar sýnir mér ávallt kurteisi.

12. Kennarar deildarinnar geta svarað spurningum mínum um námsefnið af pekkingu.

13. Ég finn að kennarar deildarinnar vilja veita mér persónulega pjónustu.

14. Starfsfólk deildarinnar hefur pekkingu til að svara spurningum mínum varðandi reglur, skráningu o.p.h.

15. Starfsfólk deildarinnar er vingjarnlegt í viðmóti.

16. Námskeiðsgögn eru til reiðu pegar ég parf á peim að halda.

Spurningarnar reyndust vera með viðunandi innri áreiðanleika en miðað var við að innri áreiðanleiki, mældur sem Cronbachs-alfa $(\alpha)$, væri ekki lægri en 0,7, sem er algengt viðmið (Groth-Marnat, 2003). Innri áreiðanleiki er mæling á pví hvort atriði kvarðans, p.e. spurningarnar, mæla sömu eða samskonar hugmynd eða ekki (DeVellis, 2003). Eftir pví sem Cronbachs-alfa er hærri (nálgast 1,0) pví einsleitari eru atriðin í viðkomandi kvarða eða spurningalista og pví líklegra er að pau mæli öll sömu hugmyndina. Reiknað alfa fyrir pær 16 spurningar sem notaðar voru í rannsókninni var 0,817 pegar spurt var um frammistöðu en ef spurningu 1 væri sleppt myndi alfa-stuðullinn hækka í 0,821 enda fellur pað atriði, félagslífið, ekki undir pjónustu skólans við nemendur heldur er pað fyrst og fremst í höndum nemendanna sjálfra.

Í öðrum hluta voru nemendur beðnir um að segja til um mikilvægi peirra sextán atriða sem fram koma í hluta eitt. Tilgangurinn með pví er að fá pað fram að atriði skipta mismiklu máli fyrir nemendur og mikilvægt er að standa sig vel í pví sem skiptir miklu máli og láta úrbætur hafa forgang pegar um er að ræða slaka frammistöðu í mikilvægu atriði. Hér er mikilvægi notað sem mælikvarði á væntingar par sem í ljós kemur að mjög sterk fylgni er á milli mikilvægis og væntinga. Reiknað alfa fyrir spurningarnar pegar spurt var um mikilvægi var 0,777.

Í priðja hluta var spurt um sex atriði. Fyrstu prjár spurningarnar tóku til afstöðu nemenda til Nemendaskrár, Uglunnar og Námsráðgjafar. Fjórða spurningin tengdist heildaránægju, fimmta fjallaði um líkur á pví að viðkomandi myndi mæla með námi við Háskóla Íslands og sjötta um líkurnar á pví hvort viðkomandi myndi aftur velja Háskóla Íslands ef verið væri að hefja nám nú. Í pessari grein er ekki fjallað sérstaklega um niðurstöður er tengjast Nemendaskrá, Uglunni eða Námsráðgjöf. Seinni prjár spurningarnar eru hins vegar notaðar til að varpa ljósi á tryggð nemenda við skólann og hvort samband er á milli heildaránægju og tryggðar.

Fjórði hluti spurningalistans tengdist bakgrunni svarenda, s.s. aldri, kyni, deild og námshraða, og er fyrst og fremst ætlaður til úrvinnslu gagnanna. 


\subsection{Greining gagna og úrvinnsla}

Eftir að gagnaöflun lauk voru gögnin flutt yfir í forritið SPSS til nánari úrvinnslu. Dreifigreining (e. ANOVA) var notuð við tölfræðilega greiningu til að kanna hvort munur væri milli hópa samkvæmt bakgrunnsbreytum og til að kanna hvort munur væri milli nemenda úr samkeppnisdeildum annars vegar og öðrum deildum hins vegar var notað t-próf. Aðeins er talað um mun í niðurstöðum pegar hann er tölfræðilega marktækur miðað við 5\% marktektarmörk.

Niðurstöður spurninga úr hluta eitt og tvö eru settar fram á radarkorti par sem samtímis má sjá afstöðu til allra pjónustuspurninganna og mikilvægis peirra. Skynjun er mæld á fimm stiga kvarða par sem 1 stendur fyrir mjög ósammála og 5 fyrir mjög sammála. Mikilvægið er einnig mælt á fimm stiga kvarða en par stendur 1 fyrir lítið mikilvægi en 5 fyrir mikið mikilvægi. Gapið eða bilið á milli frammistöðu og mikilvægis er hið eiginlega pjónustugap. Mikið bil pýðir oftast að um er að ræða slaka frammistöðu í mikilvægu atriði og pví stærra sem bilið er pví brýnni eru úrbætur. Par sem t-próf sýnir marktækan mun eru pær niðurstöður settar fram í töfluformi.

Til að kanna sambandið milli heildaránægju og tryggðar eru notaðir fylgniútreikningar og aðhvarfsgreining par sem kannað er hvort marktæk fylgni sé á milli heildaránægju og pess hvort nemendur séu líklegir til að mæla með námi við skólann annars vegar og hvort viðkomandi nemandi myndi velja aftur skólann ef hann væri að hefja nám nú hins vegar. Petta er bæði skoðað fyrir heildarniðurstöður en einnig eftir samkeppnisstigi.

\subsection{Niðurstöður}

Niðurstöðukaflanum er skipt upp í fjóra undirkafla. Fyrst er gerð grein fyrir niðurstöðu pjónustumats par sem stuðst er við gapsgreiningu en í henni er lagt mat á bilið milli skynjaðrar frammistöðu annars vegar og mikilvægis hins vegar. Út frá peim niðurstöðum er dregið fram hvar um er að ræða styrk eða veikleika. Í kafla tvö er fengist við tilgátu 1: Nemendur í samkeppnisdeildum hafa meiri væntingar en nemendur i öđrum deildum. Gengið er út frá pví að aukið val, og par með aukin samkeppni, hafi pau áhrif á væntingar að kröfur verði meiri. Í kafla prjú er tekist á við tilgátu 2: Umburðarlyndi nemenda í samkeppnisdeildum er minna en nemenda í öðrum deildum. Par er gengið út frá pví að aukið val, og par með aukin samkeppni, hafi pau áhrif að pjónustan sé dæmd harðar par sem samkeppni er til staðar en í öðrum deildum, sem hefur pau áhrif að pjónustugapið verður meira. Í undirkafla fjögur er fengist við tilgátu 3: Nemendur i samkeppnisdeildum eru ekki eins tryggir skólanum og nemendur annarra deilda. Stuðst er við tvær spurningar sem mæla tryggð, líkur á pví nemendur mæli með skólanum annars vegar og hins vegar líkur á pví að peir veldu skólann aftur væru peir að hefja nám nú. Í sama kafla er tekist á við tilgátu 4: Sterkt samband er á milli heildaránægju og tryggðar við skólann. Par er gengið út frá pví að pví ánægðari sem viðkomandi er með frammistöðuna pví tryggari skólanum sé hann. 


\subsubsection{Niðurstaða pjónustumats}

Á mynd 5 má sjá heildarniðurstöður fyrir bæði árin settar fram á radarkorti. Við tölfræðilega greiningu kemur í ljós að munur milli ára er óverulegur, hvort sem um væntingar eða skynjun er að ræða. Skynjunin er sýnd með heilu óreglulegu línunni og mikilvægið með óreglulegu punktalínunni. Efri og neðri mörk eru til viðmiðunar. Frammistaða fyrir ofan efri mörk $(4,12)$ er styrkur en frammistaða fyrir neðan neðri mörk $(3,64)$ er veikleiki (sjá t.d. Heskett, Sasser og Schlesinger, 1997). Í peirri framsetningu sem hér er kynnt er litið svo á að um styrk sé að ræða lendi bæði skynjun og mikilvægi fyrir ofan efri mörk en að um veikleika sé að ræða lendi mikilvægið fyrir ofan efri mörk en frammistaðan (skynjunin) fyrir neðan neðri mörk. Pau atriði ættu að njóta forgangs hvað úrbætur varðar.

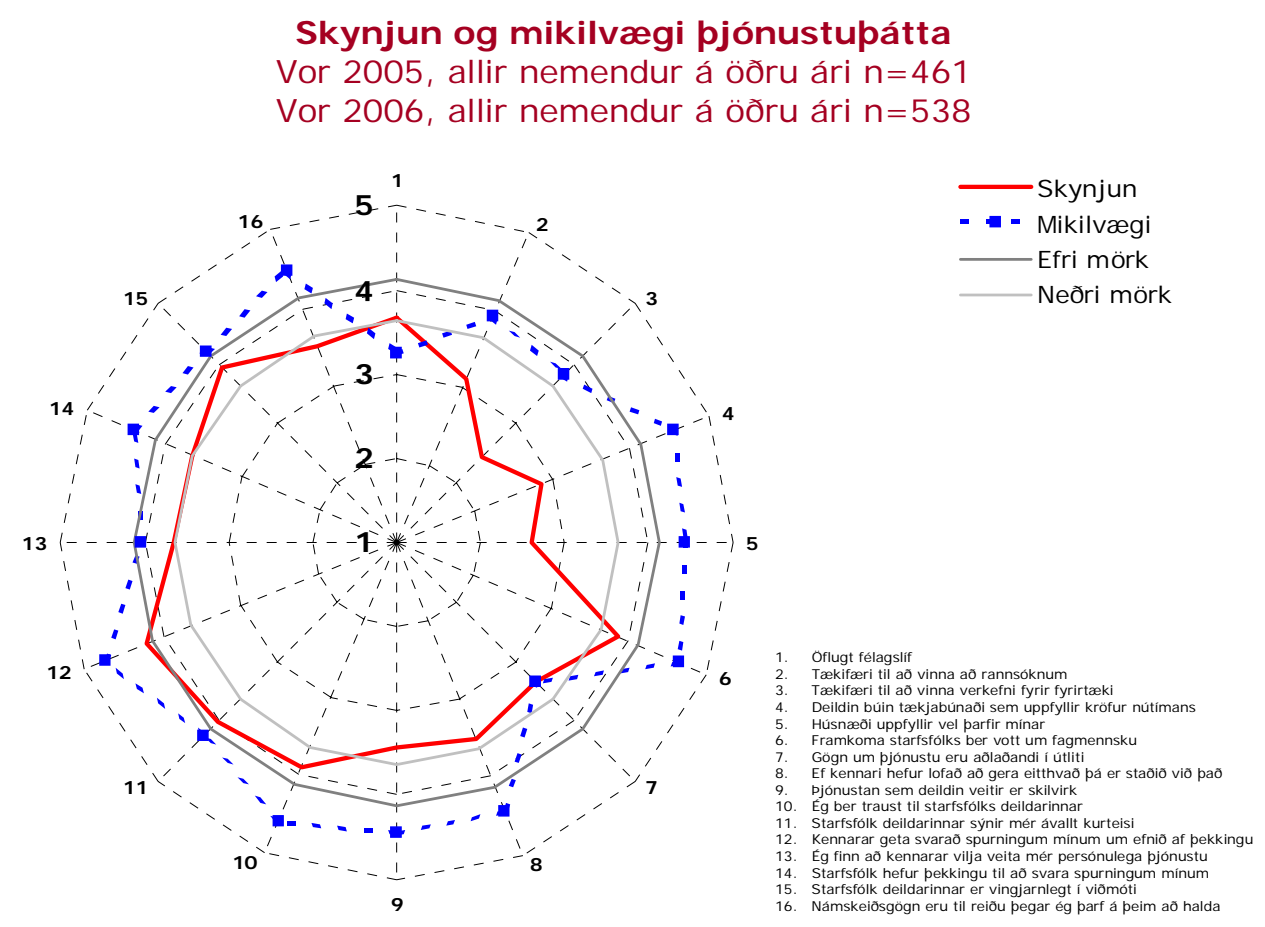

Mynd 5. Skynjun og mikilvægi pjónustupátta, heildarniðurstöður

Eins og sjá má á mynd 5 eru nokkur atriði sem teljast til veikleika samkvæmt framangreindri skilgreiningu. Petta eru atriði 4, 5, 8, 9 og 16. Styrkur kemur fram í einu atriði, p.e. atriði 12, og má segja að fyrir háskóla sé pað atriði mjög mikilvægt. Veikleikarnir tengjast umgjörð, s.s. húsnæði og tækjabúnaði, en einnig áreiðanleika og viðbrögðum. Skólinn ætti pví að leggja áherslu á úrbætur í peim atriðum.

\subsection{2 Áhrif samkeppni á væntingar}

Hér er fengist við pá tilgátu að nemendur í samkeppnisdeildum hafi meiri væntingar til frammistöðu en nemendur í peim deildum sem búa við minni 
samkeppni. Niðurstöður eru settar fram á mynd 6 og benda til pess að væntingar nemenda til pjónustu séu í grundvallaratriðum svipaðar, óháð pví hvort peir tilheyra samkeppnisdeildum eða öðrum deildum. Pó kemur fram marktækur munur í nokkrum atriðum.

Mikilvægi pjónustupátta

Nemendur á öðru ári 2005 og 2006 n=999

Skipt eftir samkeppnisstigi

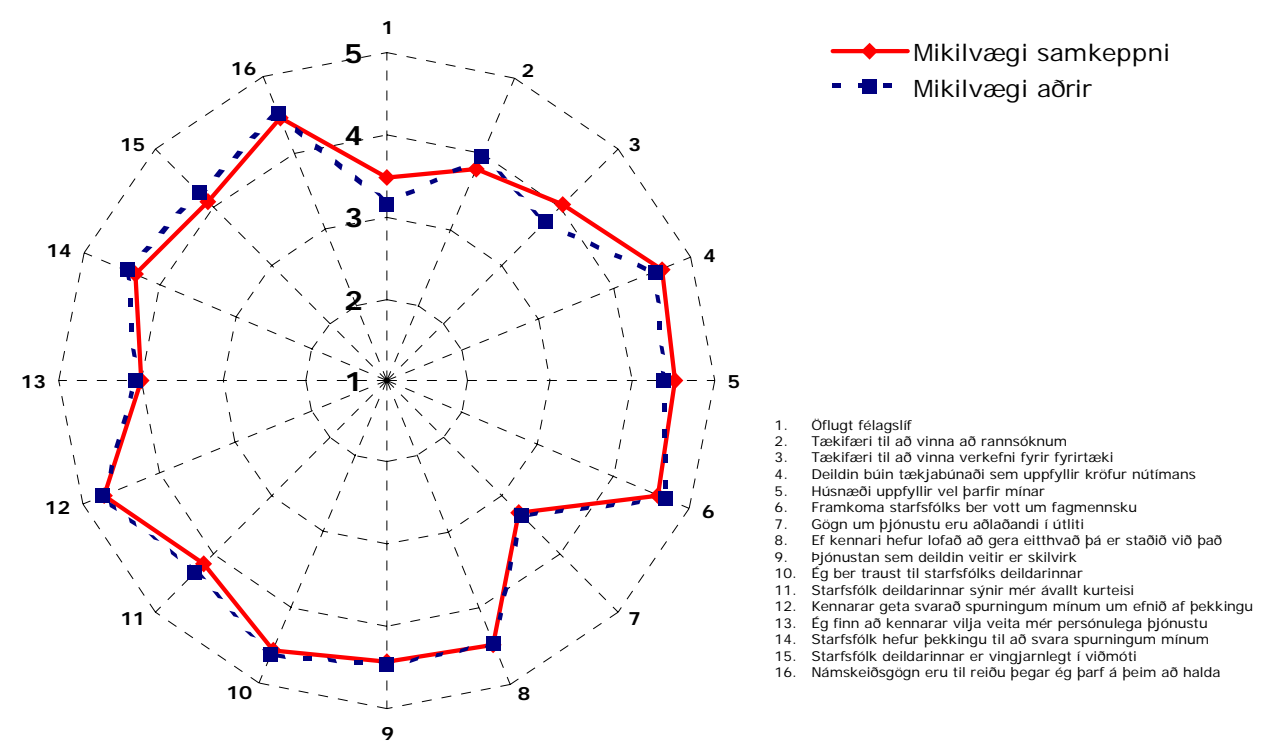

Mynd 6. Mikilvægi pjónustupátta, skipt eftir samkeppnisstigi

Pannig pykir nemendum samkeppnisdeilda öflugt félagslíf (sp.1) mikilvægara en nemendum í öðrum deildum. Nemendum í öðrum deildum finnst mikilvægara að fá tækifæri til að vinna að rannsóknum (sp.2) en nemendum samkeppnisdeildanna og nemendum samkeppnisdeilda finnst mun mikilvægara að fá að vinna verkefni fyrir fyrirtæki og stofnanir (sp.3) en nemendum annarra deilda. Nemendur í samkeppnisdeildunum leggja meira upp úr húsnæði (sp.5) en nemendur annarra deilda en nemendum annarra deilda finnst aftur á móti kurteisi starfsfólks (sp.11) mikilvægari en nemendum samkeppnisdeildanna. Með sama hætti finnst nemendum annarra deilda pekking starfsmanna til að svara fyrirspurnum (sp.14) mikilvægari en nemendum samkeppnisdeildanna. Nemendum annarra deilda finnst enn fremur vingjarnlegt viðmót (sp.15) mikilvægara en nemendum samkeppnisdeildanna. Samantekt á marktækni t-prófs má sjá í töflu 1 . 
Tafla 1. Marktæknistig væntingaspurninga

\begin{tabular}{l|l|r|r}
\hline Spurning & \multicolumn{1}{|c|}{ Marktækni } & $\begin{array}{c}\text { Samkeppnis- } \\
\text { deildir }\end{array}$ & $\begin{array}{c}\text { Aðrar } \\
\text { deildir }\end{array}$ \\
\hline sp 1 & $\mathrm{t}(997)=3,56 ; P<0,05$ & 3,33 & 3,03 \\
\hline sp 2 & $\mathrm{t}(997)=-2,46 ; \mathrm{P}<0,05$ & 3,80 & 3,98 \\
\hline sp 3 & $\mathrm{t}(644)=4,35 ; \mathrm{P}<0,05$ & 4,04 & 3,73 \\
\hline sp 5 & $\mathrm{t}(997)=2,82 ; \mathrm{P}<0,05$ & 4,52 & 4,37 \\
\hline sp 11 & $\mathrm{t}(997)=-2,04 ; \mathrm{P}<0,05$ & 4,18 & 4,30 \\
\hline sp 14 & $\mathrm{t}(506)=-2,09 ; \mathrm{P}<0,05$ & 4,32 & 4,44 \\
\hline sp 15 & $\mathrm{t}(997)=-2,44 ; \mathrm{P}<0,05$ & 4,10 & 4,23 \\
\hline
\end{tabular}

Hér parf að hafa í huga að vera kann að aðrar ástæður en samkeppni séu fyrir pví að fram komi tölfræðilega marktækur munur milli nemenda samkeppnisdeilda og nemenda annarra deilda. Pannig kann раð аð vera аð nemendur sem sæki samkeppnisdeildir séu öðruvísi að eðlisfari en nemendur annarra deilda og geri pess vegna aðrar kröfur, og líklegt er að nemendur sem stunda nám í svo kölluðum hagnýtum greinum leggi meira upp úr hagnýtum verkefnum en nemendur annarra deilda. Gögnin sem hér er stuðst við gefa hins vegar ekki svigrúm til að kanna hvort munur sé á persónuleika eða bakgrunni pessara tveggja hópa.

Ef niðurstöður eru teknar saman má segja að nemendur samkeppnisdeilda virðist leggja meira upp úr ápreifanleika og umgjörð en nemendur annarra deilda en nemendur annarra deilda virðist leggja meira upp úr hluttekningu en nemendur samkeppnisdeildanna. Hér parf pó að hafa í huga að prátt fyrir að fram komi tölfræðilega marktækur munur á tilteknu atriði, pá er pað atriði verið mikilvægt fyrir nemendur í öllum deildum. Petta má sjá á mynd 6. Mesti afgerandi munurinn sem fram kemur í einu tilteknu atriði varðar tækifæri til að vinna verkefni fyrir fyrirtæki og stofnanir. Nemendum samkeppnisdeilda finnst pað mikilvægara en nemendum í öðrum deildum. Рað parf í sjálfu sér ekki að koma á óvart par sem skilgreindar samkeppnisdeildir eru í eðli sínu hagnýtar. Petta bendir til pess að hugsanlega ættu samkeppnisdeildirnar að auka möguleika nemenda sinna á pví að vinna hagnýt verkefni, sem og að efla tengsl sín við atvinnulífið. Niðurstaðan er pví sú að ekki sé hægt nema að litlu leyti að styðja pá tilgátu að nemendur samkeppnisdeilda hafi meiri væntingar til pjónustu en nemendur annarra deilda.

\subsection{3 Áhrif samkeppni á skynjaða frammistöðu}

Pegar afstaða til frammistöðu (skynjun) er skoðuð kemur fram að nemendur í samkeppnisdeildunum gefa skólanum almennt lægri einkunn en nemendur í öðrum deildum, p.e. í prettán af sextán atriðum. Heildarniðurstöður má sjá á mynd 7. 


\section{Skynjun frammistöðu}

Nemendur á öðru ári 2005 og 2006 n=999

Skipt eftir samkeppnisstigi

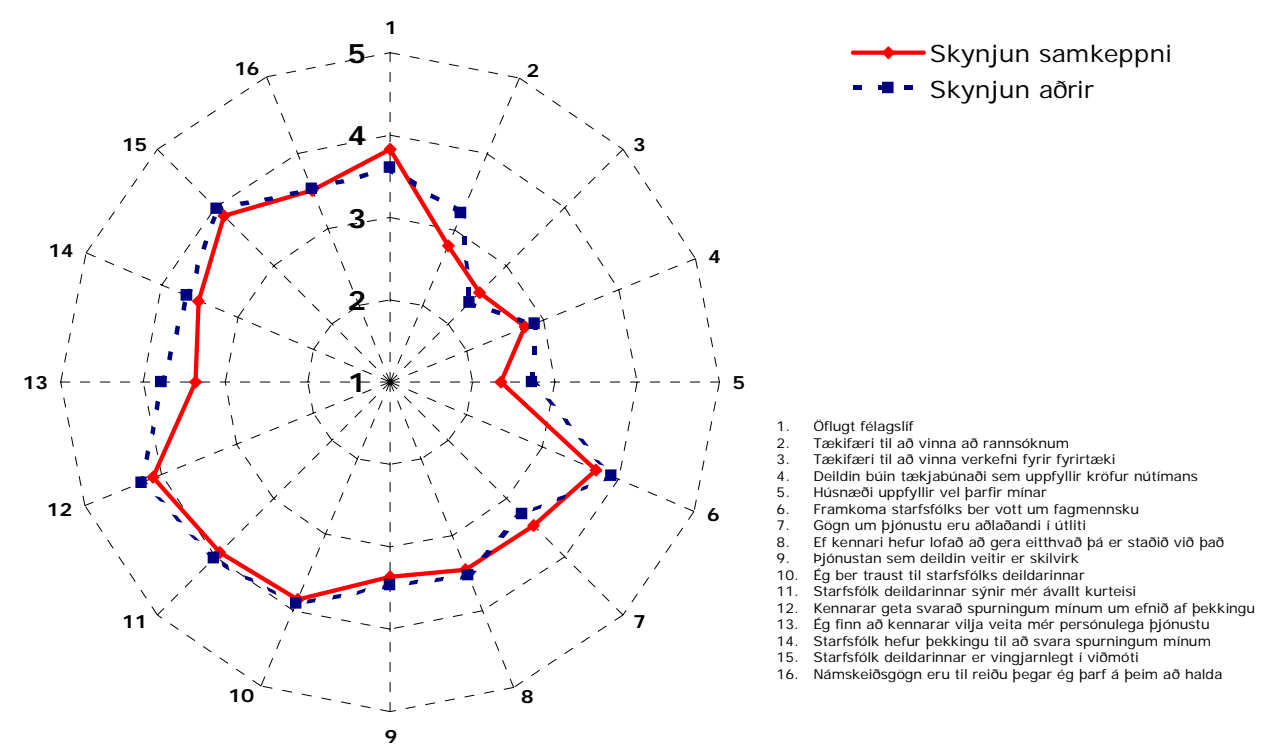

Mynd 7. Skynjuð frammistaða, skipt eftir samkeppnisstigi

Petta bendir til pess að samkeppni, p.e. aukið val, hafi áhrif á umburðarlyndi peirra er pjónustunnar njóta. Í nokkrum tilvikum kemur fram tölfræðilega marktækur munur. Nemendur samkeppnisdeilda telja fremur en nemendur annarra deilda að við skólann sé öflugt félagslíf (sp.1). Hins vegar telja nemendur annarra deilda fremur en nemendur samkeppnisdeildanna að peir fái tækifæri til að stunda rannsóknir (sp.2). Nemendur samkeppnisdeildanna telja hins vegar frekar en nemendur annarra deilda að peir fái tækifæri til að vinna verkefni fyrir fyrirtæki og stofnanir (sp.3). Lág einkunn fyrir petta atriði gerir pað verkum að réttara væri að segja að nemendur samkeppnisdeildanna séu ekki eins ósammála fullyrðingunni og nemendur annarra deilda.

Nemendur samkeppnisdeildanna virðast einnig óánægðari með húsnæðismálin (sp.5) en nemendur annarra deilda. Lág einkunn hjá báðum hópum bendir pó til pess að óánægja með húsnæðismál sé almenn og ef marka má heildarniðurstöður (sjá mynd 5) virðist sem hér sé um mikinn veikleika að ræða hjá Háskóla Íslands. Nemendur samkeppnisdeildanna eru einnig óánægðari með faglega framkomu starfsfólks (sp.6) en nemendur annarra deilda. Niðurstöður á mynd 7 benda hins vegar ekki til pess að hér sé um mikilvægan veikleika að ræða.

Pegar kemur að pví hvort kennslugögn séu aðlaðandi í útliti (sp.7) eru nemendur annarra deilda en samkeppnisdeildanna óánægðari með pað atriði en nemendur samkeppnisdeildanna. Heildarniðurstöðurnar á mynd 5 benda hins vegar til pess að mikilvægi pessa atriðis sé mjög lítið og er petta atriði annað af tveimur par sem einkunn fyrir frammistöðu er hærri en einkunn fyrir mikilvægi. Nemendur 
annarra deilda en samkeppnisdeildanna telja frekar að kennarar geti svarað spurningum nemenda um námsefnið af pekkingu (sp.12) en nemendur samkeppnisdeilda en í báđum tilvikum er einkunn pað há að um styrk fyrir báða hópa er að ræða. Nemendur samkeppnisdeildanna telja síður en nemendur annarra deilda að kennarar vilji veita peim persónulega pjónustu (sp.13) og pað sama gildir um að starfsfólk deilda hafi pekkingu til að svara spurningum (sp.14). Nemendur samkeppnisdeildanna eru enn fremur síður sammála peirri fullyrðingu að starfsfólk deildarinnar sé vingjarnlegt í viðmóti (sp.15) en nemendur annarra deilda. Samantekt á marktækni t-prófs má sjá á töflu 2.

Tafla 2. Marktæknistig frammistöðuspurninga

\begin{tabular}{l|l|r|r}
\hline Spurning & \multicolumn{1}{|c|}{ Marktækni } & $\begin{array}{c}\text { Samkeppnis- } \\
\text { deildir }\end{array}$ & $\begin{array}{c}\text { Aðrar } \\
\text { deildir }\end{array}$ \\
\hline sp 1 & $\mathrm{t}(469)=2,93 ; P<0,05$ & 3,81 & 3,60 \\
\hline sp 2 & $\mathrm{t}(997)=-6,2 ; \mathrm{P}<0,05$ & 2,81 & 3,24 \\
\hline sp 3 & $\mathrm{t}(996)=2,38 ; \mathrm{P}<0,05$ & 2,55 & 2,38 \\
\hline sp 5 & $\mathrm{t}(997)=-4,80 ; \mathrm{P}<0,05$ & 2,32 & 2,72 \\
\hline sp 6 & $\mathrm{t}(536)=-3,03 ; \mathrm{P}<0,05$ & 3,73 & 3,91 \\
\hline sp 7 & $\mathrm{t}(995)=2,89 ; \mathrm{P}<0,05$ & 3,47 & 3,28 \\
\hline sp 12 & $\mathrm{t}(995)=-2,61 ; \mathrm{P}<0,05$ & 4,12 & 4,24 \\
\hline sp 13 & $\mathrm{t}(539)=-6,24 ; \mathrm{P}<0,05$ & 3,35 & 3,77 \\
\hline sp 14 15 & $\mathrm{t}(996)=-2,15 ; \mathrm{P}<0,05$ & 3,55 & 3,68 \\
\hline
\end{tabular}

Ef niðurstöðurnar eru teknar saman virðast nemendur samkeppnisdeilda gefa lægri einkunn en nemendur annarra deilda fyrir atriði er tengjast trúverðugleika og hluttekningu og nemendur annarra deilda gefa aftur á móti lægri einkunn fyrir atriði sem tengjast umgjörð. Раð á pó ekki við um húsnæði par sem nemendur samkeppnisdeilda gefa mun lægri einkunn en nemendur annarra deilda. Almennt séð gefa nemendur samkeppnisdeilda skólanum lægri einkunn fyrir frammistöðu en aðrir nemendur og par sem í mörgum tilvikum er um sameiginleg atriði að ræða, p.e. atriði sem eru ekki háð frammistöðu deilda, bendir petta til pess að samkeppni hafi áhrif á umburðarlyndi nemenda. Pví meiri sem samkeppnin er pví minna sé umburðarlyndið. Niðurstaðan er pví sú að tilgátan um að umburðarlyndi nemenda í samkeppnisdeildum sé minna en nemenda í öðrum deildum sé rétt.

\subsection{4 Áhrif samkeppni á tryggð}

Til að leggja mat á tryggð var stuðst við tvær spurningar. Sú fyrri var „Hversu líklegt eða ólíklegt er að pú myndir mæla með náminu?“ en sú seinni „Ef pú værir að hefja nám nú, hversu líklegt eða ólíklegt er að pú myndir velja Háskóla Íslands?“. Spurningarnar eru báđar taldar vera mælikvarði á tryggð í umhverfi pví sem háskólar starfa í (Christensen, 2004).

Á mynd 8 má sjá niðurstöður fyrir fyrri spurninguna, skipt eftir samkeppnisstigi. Eins og sjá má eru báðir hóparnir mjög líklegir til að mæla með 
námi við Háskóla Íslands en t-próf sýndi að ekki er um marktækan mun að ræða milli samkeppnisdeilda $(\mathrm{S}=4,06, \mathrm{SD}=1,054)$ og annarra deilda $[\mathrm{A}=4,16, \mathrm{SD}=0,841$; $\mathrm{t}(997)=-1,65, \mathrm{p}=0,1]$.

Hversu líklegt er að pú myndir mæla með námi við

Háskóla Íslands?

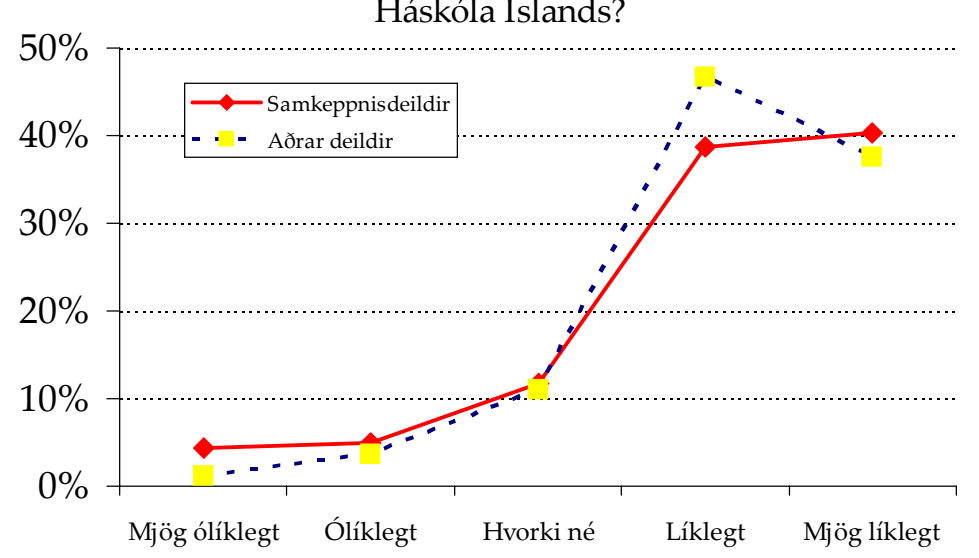

Mynd 8. Líkur á pví viðkomandi mæli með námi við Háskóla Íslands

Fram kemur að 9,3\% (+/- 3,3\%) nemenda í samkeppnisdeildunum telja mjög ólíklegt eða ólíklegt að peir muni mæla með náminu en 4,7\% (+/- 1,6\%) nemenda annarra deilda telja pað mjög ólíklegt eða ólíklegt. Við nánari greiningu gagnanna kemur í ljós að nokkur munur er innbyrðis milli samkeppnisdeildanna. Sökum trúnaðar og eðlis upplýsinganna er ekki gerlegt að gera grein fyrir peim muni hér.

Seinni spurningin sem notuð var til að leggja mat á tryggð við skólann eða deildina var spurning er sneri að líkunum á pví að viðkomandi veldi aftur Háskóla Íslands væri hann að hefja nám nú. Par var spurt: „Ef pú værir núna að skrá pig til náms, hversu líklegt er að pú veldir Háskóla Íslands?" Á mynd 9 má sjá að hér munar nokkru eftir pví hvort nemandinn tilheyrir samkeppnisdeild eða öðrum deildum. Pannig telja 23,1\% (+/- 4,7\%) nemenda samkeppnisdeildanna pað mjög ólíklegt eða ólíklegt að peir myndu velja aftur Háskóla Íslands væru peir að hefja nám nú en $8,8 \%(+/-2 \%)$ nemendur annarra deilda telja pað mjög ólíklegt eða ólíklegt. Niðurstöður t-prófs sýna að marktækur munur er á milli samkeppnisdeilda $(\mathrm{S}=3,77, \mathrm{SD}=1,342)$ og annarra deilda $[\mathrm{A}=4,22, \mathrm{SD}=1 ; \mathrm{t}(995)=-5,8, \mathrm{p}<0,001]$. 
Ef pú væri núna að skrá pig til náms, hversu líklegt er að pú veldir Háskóla Íslands?

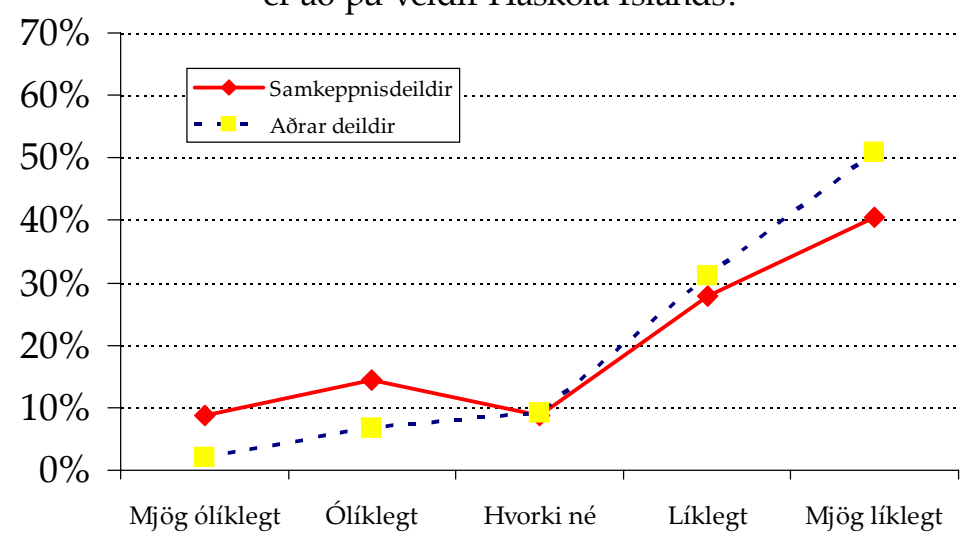

Mynd 9. Líkur fyrir pví að velja Háskóla Íslands aftur

Á mynd 9 má sjá að mun hærra hlutfall annarra nemenda en nemenda samkeppnisdeildanna telja pað líklegt eða mjög líklegt að peir myndu velja Háskóla Íslands aftur (82\% (+/-2,8\%). Hlutfall nemenda í samkeppnisdeildum sem telja pað líklegt eða mjög líklegt er 68,3\% (+/- 5,3\%). Af niðurstöðunum má pví draga pá ályktun að nemendur deilda par sem samkeppni er lítil eða engin séu líklegri en nemendur samkeppnisdeildanna til að velja Háskóla Íslands aftur væru peir að hefja nám nú og séu í peim skilningi tryggari skólanum en nemendur samkeppnisdeildanna. Svörin við fyrri spurningunni sem fjallar um tryggð (líkurnar á pví að nemandi mæli með Háskóla Íslands) styðja ekki pá tilgátu að nemendur samkeppnisdeilda séu ótryggari en nemendur annarra deilda. Svörin við seinni spurningunni (líkurnar á pví að nemandi veldi Háskóla Íslands aftur) benda hins vegar til pess að nemendur samkeppnisdeilda séu ekki eins tryggir skólanum og nemendur annarra deilda.

Fyrr í pessari grein er fjallað um sambandið milli ánægju og tryggðar og gengið er út frá pví að pví ánægðari sem viðskiptavinir eru pví meiri tryggð sýni peir viðkomandi vöru eða fyrirtæki. Til að kanna petta var spurt um heildaránægju og spurningin var: „Pegar á heildina er litið, hversu ánægð(ur) eða óánægð(ur) ertu með veru pína í Háskóla Íslands?“ Niðurstöđurnar, skipt eftir samkeppnisstigi, má sjá á mynd 10. Eins og par má sjá er nánast enginn munur á heildaránægju nemenda, hvort sem peir tilheyra samkeppnisdeildum eða öðrum deildum, langflestir (83,7\%) eru, pegar á heildina er litið, ánægðir með veru sína í Háskóla Íslands. 
Á heildina litið, hversu ánægð(ur) ertu með veru

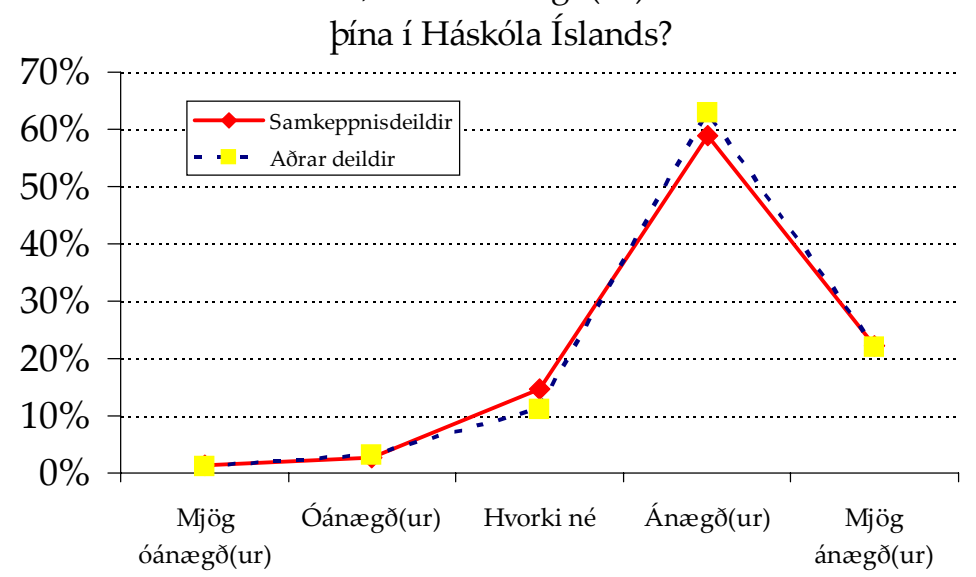

Mynd 10. Heildaránægja nemenda með veru sína í Háskóla Íslands

Nánari greining á gögnunum bendir ekki til pess að um innbyrðis breytileika sé að ræða meðal samkeppnisdeildanna eins og kom fram í fyrri spurningunni sem fjallar um tryggð. ANOVA-greining sýnir enn fremur að ekki kemur fram marktækur munur milli háskóladeilda sé miðað við 5\% marktektarmörk.

Til að skoða sambandið milli heildaránægju og tryggðar var reiknað út fylgnifylki milli peirra priggja spurninga sem notaðar voru til að mæla tryggð og heildaránægju. Niðurstöður fyrir reiknað fylgnifylki má sjá á mynd 11.

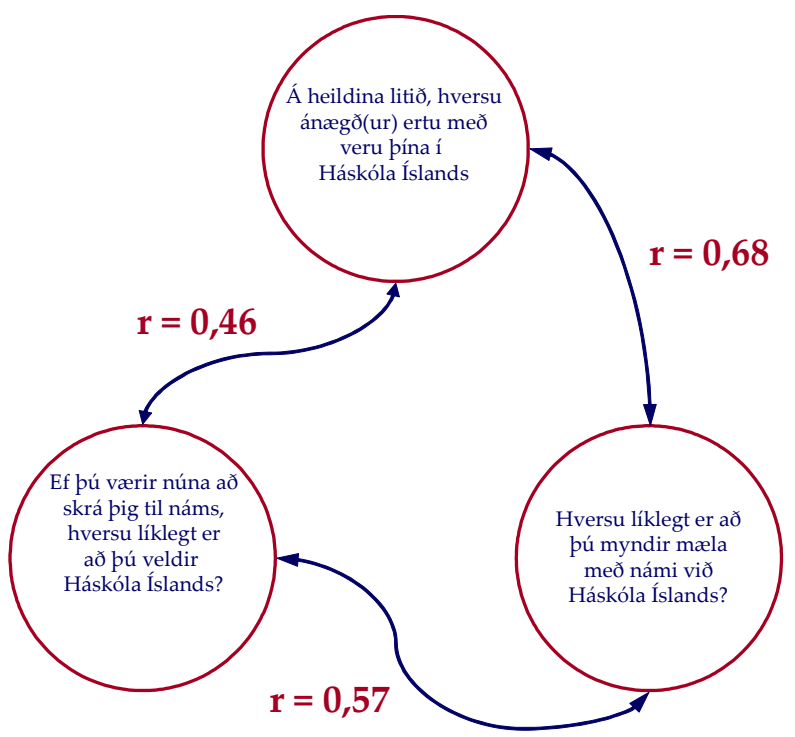

Mynd 11. Fylgni milli heildaránægju og tryggðar 
Við útreikning á fylgni var stuðst við Pearson-r, sem er eðlilegt par sem um jafnbilakvarða er að ræða (Einar Guðmundsson og Árni Kristjánsson, 2005). Nokkuð skiptar skoðanir eru á pví með hvaða hætti eigi að túlka fylgnistuðlana. Pannig benda Burns og Bush (2000) á að fylgni á bilinu 0,81-1 sé sterk, á bilinu 0,61-0,8 í meðallagi, á bilinu 0,41-0,6 sé hún veik, á bilinu 0,21-0,4 mjög veik og á bilinu 0,0-0,2 sé engin fylgni milli breyta. Cohen (1988) leggur hins vegar til pau viðmið að fylgni á bilinu 0,5-1 sé sterk, á bilinu 0,3-0,49 sé hún í meðallagi og á bilinu 0,1-0,29 sé hún veik. Sé miðað við pá skilgreiningu má sjá að sterkt samband er á milli heildaránægju og líkanna á pví að nemandi mæli með námi við Háskóla Íslands. Sambandið er í meðallagi á milli heildaránægju og líkanna á pví að viðkomandi myndi velja Háskóla Íslands aftur væri hann að hefja nám nú. Af pessu er dregin sú ályktun að sambandið milli heildaránægju og líkanna á að mæla með námi við skólann sé mikilvægt og pví vert að skoða pað nánar. Á mynd 12 má sjá petta samband sem línulegt en stundum hefur sambandið verið sett fram sem veldisfall (Heskett, Sasser og Schlesinger, 1997).

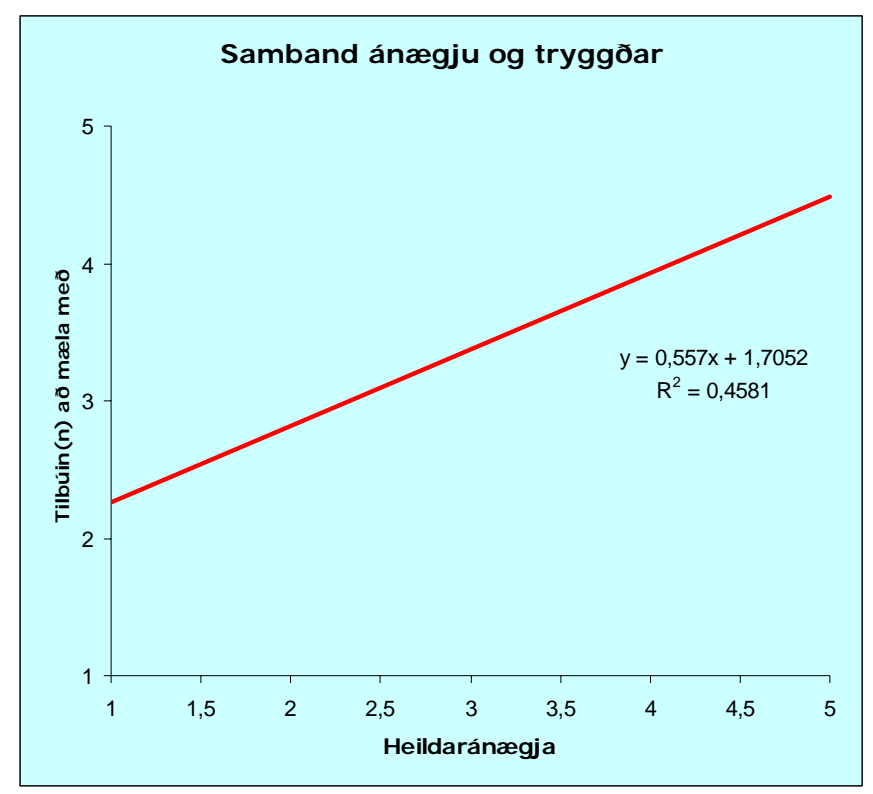

Mynd 12. Samband ánægju og tryggðar

Eins og áður hefur komið fram er petta samband sterkt og útskýringarhlutfallið $\left(R^{2}\right)$ er 0,4581. Pað má túlka sem svo að heildaránægja útskýri um $46 \%$ af líkunum á pví að viðkomandi mæli með námi við Háskóla Íslands. 


\section{Umræða}

Markmið pessarar greinar var að skoða áhrif samkeppni á væntingar, skynjun og tryggð við pjónustutilboð. Fjallað var um mismunandi skilgreiningar á samkeppni, væntingar, skynjun og tryggð. Rannsóknarkaflinn var byggður á gögnum úr viðhorfskönnun meðal annars árs nema við Háskóla Íslands. Um var að ræða megindlega rannsókn par sem viðhorf nemenda til pjónustu Háskóla Íslands var kannað.

Í rannsókninni er unnið út frá rannsóknarspurningunni: „Hefur samkeppni einhver áhrif á væntingar, skynjun og tryggð viðskiptavina?“ Í tengslum við rannsóknarspurninguna og pá fræðilegu umfjöllun sem finna má í greininni voru settar fram fjórar tilgátur.

Fyrsta tilgátan sneri að pví að nemendur í samkeppnisdeildum hefðu meiri væntingar til pjónustu en nemendur í öðrum deildum. Niðurstöður bentu til pess að í grundvallaratriðum væru væntingar nemenda svipaðar hvort sem peir tilheyrðu samkeppnisdeildum eða öðrum deildum. Nemendur samkeppnisdeildanna virtust pó leggja meira upp úr ápreifanleika og umgjörð en nemendur annarra deilda á meðan að peir lögðu aftur á móti meira upp úr hluttekningu. Mesti afgerandi munurinn milli hópanna sneri að tækifærinu til að vinna verkefni fyrir fyrirtæki og stofnanir, svokölluðum raunverkefnum. Раð fannst nemendum samkeppnisdeildanna mikilvægara en nemendum annarra deilda. Pessi niðurstaða parf ekki að koma á óvart enda má skilgreina viðskiptafræði, verkfræði og lögfræði sem hagnýtar greinar.

Önnur tilgátan sneri að pví að umburðarlyndi nemenda í samkeppnisdeildum væri minna en nemenda í öðrum deildum. Niðurstöður bentu til pess að svo væri. Nemendur í samkeppnisdeildunum gáfu almennt séð lægri einkunnir en nemendur í öðrum deildum og var um tölfræðilega marktækan mun að ræða í 10 atriðum af 16. Petta bendir til pess að aukið val, p.e. samkeppni, hafi áhrif á umburðarlyndi peirra er pjónustunnar njóta. Pví meira val sem peir hafa pví síður eru peir umburðarlyndir.

Priðja tilgátan tengdist tryggð en par var gengið út frá pví að nemendur samkeppnisdeilda væru ekki eins tryggir skólanum og nemendur annarra deilda. Hér var tryggð metin sem vilji viðkomandi til að mæla með pjónustunni við aðra og velja hana aftur ef hann væri í peim sporum að hefja nám nú. Niðurstöður bentu til pess að styðja mætti tilgátuna. Í svörunum við fyrri spurningunni kom pó ekki fram tölfræðilega marktækur munur en munurinn var nokkuð afgerandi í svörum við peirri seinni. Par mátti fullyrða með 95\% vissu að nemendur samkeppnisdeilda væru ólíklegri en nemendur annarra deilda til að velja Háskóla Íslands aftur væru peir að hefja nám nú. Rétt er pó að fram komi að tæp 70\% nemenda samkeppnisdeildanna telja líklegt að peir veldu Háskóla Íslands aftur væru peir að hefja nám nú. Hvað svör við fyrri spurningunni varðar kom fram að nokkur munur væri innbyrðis milli samkeppnisdeildanna. Ein af peim skar sig nokkuð úr en par voru nemendur einna líklegastir til að mæla með námi við skólann/deildina. Nemendur í hinum tveimur samkeppnisdeildunum voru ólíklegastir til að mæla með námi við skólann. Pessi 
mismunur milli samkeppnisdeildanna gerði pað að verkum að ekki kom fram marktækur munur milli samkeppnisdeildanna annars vegar og annarra deilda hins vegar.

Fjórða tilgátan gekk út á að sterkt samband væri á milli heildaránægju og tryggðar. Í niðurstöðum kom ekki fram munur á milli hópa pegar heildaránægja var skoðuð, sem er athyglisvert í ljósi pess að nemendur samkeppnisdeilda gáfu alla jafna lægri einkunn fyrir frammistöðu í pjónustupáttum en nemendur annarra deilda og margt benti til pess að peir væru ekki eins tryggir skólanum og peir. Rétt er að undirstrika að langflestir nemendur voru ánægðir með veru sína í Háskóla Íslands, eða tæp $84 \%$. Í niðurstöðum kom fram sterkt samband á milli heildaránægju og tryggðar. Pví ánægðari sem nemendur voru pví líklegri voru peir til að mæla með náminu og velja Háskóla Íslands aftur væru peir að hefja nám nú. Sú staðreynd að flestir nemendur gáfu skólanum góða einkunn pegar spurt var um heildaránægju benti pó til pess að ekki væri mikið svigrúm til að auka tryggð með pví að auka heildaránægju. Гаð benti til pess að utanaðkomandi atriði, eins og samkeppni, hefði bein áhrif á tryggð og pær deildir sem búa við meiri samkeppni en aðrar purfi einfaldlega að gera ráð fyrir pví og haga starfi sínu í samræmi við pað. Pessar deildir væru pví með nokkuð augljósum hætti að færast af seljandamarkaði, par sem seljandi vöru eða pjónustu hefur öll tromp í hendi sér, yfir á kaupendamarkað par sem samningskraftur kaupenda er mun meiri.

Frekari rannsóknir á pessu sviði eru mikilvægar og áhugaverðar. Mikil breyting hefur átt sér stað í opinberri pjónustu undanfarin ár. Í mörgum tilvikum hefur pjónustan verið færð frá hinu opinbera til einkaaðila, stundum hefur rekstrarformi verið breytt og í sumum tilvikum hefur verið opnað fyrir pann möguleika að aðrir aðilar geti keppt á peim markaði sem hið opinbera fyrirtæki/stofnun starfaði eitt á áđur. Líklegt er að próun sem pessi muni halda áfram á ýmsum sviðum. Раð gerir раð аð verkum að full ástæða er fyrir margs konar fyrirtæki og stofnanir sem stunda opinbera starfsemi að endurskoða starfsaðferðir sínar. Samkeppnin mun hafa pau áhrif að pjónustan verður valkvæmari en áður og kröfur til gæða pjónustunnar munu að sama skapi aukast. 


\section{Heimildir}

Andreasen, A.R. og Kotler, P. (2003). Strategic Marketing for NonProfit Organization. New Jersey: Prentice Hall.

Andreassen, T.W. (1994). Satisfaction, Loyalty and Reputation as Indicators of Customer Orientation in the Public Sector. The International Journal of Public Sector Management, 7, 16-34.

Ágúst Einarsson (2005). Rekstrarhagfræði. Reykjavík: Mál og menning.

Berry, L., Parasuraman, A. og Zeithaml, V.A. (1993). Ten Lessons for Improving Service Quality. Marketing Science Institiute, 93-104.

Bitner, M.J. (1993). Managing the Evidence of Service. Í The Service Quality Handbook, ritstj. E.E. Scheuing og W.F. Christopher. New York: Free Press, bls. 358-370.

Boulding, W., Kalra, A., Staelin, R. og Zeithaml, V.A. (1993). A Dynamic Process Model of Service Quality: From Expectations to Behavioral Intentions. Journal of Marketing Research, 30, 7-27.

Brady, M.K. og Cronin, J. (2001). Some New Thoughts on Conceptualizing Perceived Service Quality: A Hierarchical Approach. Journal of Marketing, 65, 34-50.

Brown, S.W. og Swartz, T.A. (1989). A Dyadic Evaluation of the Professional Service Encounter. Journal of Marketing, 53, 92-98.

Bruhn, M. og Georgi, D. (2006). Services Marketing. Managing the Service Value Chain. Essex: Pearson Education Limited.

Burns, A.C. og Bush, R.F. (2000). Marketing Research. New Jersey: Prentice Hall.

Chang, P.C. (2006). A Multilevel Exploration of Factors Influencing the Front-Line Employees' Service Quality in International Tourist Hotels. Journal of American Academy of Business, 9, 285-293.

Christensen, S. (2004). The virtue of satisfied client: investigating student perceptions of service quality. Í Virtue of Marketing. Academy of Marketing Conference 2004. Cheltenham: University of Cloucestershire

Christopher, M., Payne, A. og Ballantyne, D. (1991). Relationship Marketing. Bringing Quality, Customer Service and Marketing Together. London: ButterworthHeinemann.

Cohen, J. (1988). Statistical power analysis for the behavioral sciences. New York: Erlbaum.

Cravens, D.W. og Piercy, N.F. (2003). Strategic Marketing. New York: McGraw-Hill Irwin.

Cronin, J.J. og Taylor, S.A. (1992). Measuring Service Quality: A Reexamination and Extension. Journal of Marketing, 56, 55-68.

DeVellis, R.F. (2003). Scale development: Theory and applications. Thousand Oaks: Sage.

Doole, I., Lancaster, P. og Lowe, R. (2005). Understanding and Managing Customers. Essex: Pearson Education. 
Einar Guðmundsson og Árni Kristjánsson (2005). Gagnavinnsla í SPSS. Reykjavík: Háskólaútgáfan.

Falzon, J.J. (1988). Met Life's Quest for Quality. The Journal of Service Marketing, 2, 61-64.

Farsad, B. og Elshennawy, A.K. (1989). Defining Service Quality Is Difficult For Service And Manufacturing Firms. Industrial Engineering, 21, 17-19.

Finn, A. og Kayande, U. (2004). Scale codification: alternative approches and their consequences. Journal of Retailing, 80, 37-52.

Fisk, R.P., Grove, S.J. og John, J. (2000). Interactive Services Marketing. New York: Houghton Mifflin Company.

Garvin, D. (1988). Managing Quality: The Strategic and Competitive Edge. New York: Free Press.

Griffin, J. (1997). Customer Loyalty: How to Earn it and How to Keep it. New York: JosseyBass.

Groth-Marnat, G. (2003). Handbook of psychological assessment. New York: John Wiley \& Sons.

Grönroos, C. (1982). Strategic Management and Marketing in the Service Sector. Helsingfors: Swedish School of Economics and Business Administration.

Grönross, C. (1988). Service Quality: The Six Criteria Of Good Perceived Service Quality. Review of Business, 9, 10-13.

Grönroos, C. (1990). Service Management and Marketing: Managing the Moments of Truth in Service Competition. Lexington: Lexington Books.

Grönroos, C. (2000). Service Management and Marketing. West Sussex: John Wiley \& Sons.

Gummesson, E. (2002). Total Relationship Marketing. London: Butterworth-Heinemann.

Gwinner, K., Gremler, D. og Bitner, M. (1988). Relational benefits in services industries: the customer perspective. Journal of Academy of Marketing Science, 26, 101-114.

Hayes, B.E. (1998). Measuring Customer Satisfaction. Survey Design, Use, and Statistical Analysis Methods. Milwaukee: ASQ Quality Press

Heskett, J.L., Sasser, E.W. og Schlesinger, L.A. (1997). The Service Profit Chain. New York: Free Press.

Higgins, G.J. (2002). Managing Expectations, the key to wealth management. The CPA Journal, 72, 9.

Hollensen, S. (2003). Marketing Management, A Relationship Approach. Essex: Pearson Education Ltd.

Kasper, H., Helsdingen, P.V. og Gabbott, M. (2006). Services Marketing Management, a Strategic Perspective. West Sussex: John Wiley \& Sons

Kotler, P. og Keller, K.L (2006). Marketing Management 12e. New Jersey: Prentice Hall. 
Kotler, P., Wong, V., Saunders, J. og Armstrong, G. (2005). Principles of Marketing. Essex: Pearson Education.

Kotler, P., Armstrong, G., Saunders, J. og Wong, V. (2001). Principles of Marketing. Essex: Pearson Education.

Laing, A. (2003). Marketing in the public sector: Towards a typology of public services. Marketing Theory, 3, 427-445.

Lehmann, D.R. og Winer, R.S. (1991). Analysis for Marketing Planning. IL: Irwin.

Levitt, T. (1960). Marketing Myopia. Harvard Business Review, 38, 45-56

Lovelock, C. og Wirtz, J. (2004). Services Marketing. People, Technology, Strategy. New Jersey: Pearson Prentice Hall.

Lovelock, C. og Wirtz, J. (2001). Services Marketing, People, Technology, Strategy. New Jersey: Prentice Hall.

McCollough, M.A., Berry, L.L. og Yadav, M.S. (2000). An Empirical Investigation of Customer Satisfaction After Service Failure and Recovery. Journal of Service Research, 3, 121-137.

Moller, K. og Halinen, A. (2000). Relationship marketing theory: its roots and direction. Journal of Marketing Management, 16, 29-54.

Oliver, R. (1977). Effect of expectation and disconfirmation on post-expense product evaluations: an alternative interpretation. Journal of Applied Psychology, 62, 480486.

Ojasalo, J. (2001). Managing customer expectations in professional services. Managing Service Quality, 11, 200-212.

Olshavsky, R. og Miller, J. (1972). Consumer expectations, product performance and perceived product quality. Journal of Marketing Research, 9, 19-21.

Palmer, A. (2001). Principles of Services Marketing. New York: McGraw-Hill.

Parasuraman, A., Berry, L.L. og Zeithaml, V.A. (1985). A Conseptual Model of Service Quality and Its Implications for Future Research. Journal of Marketing, 49, 41-51.

Parasuraman, A., Berry, L.L. og Zeithaml, V.A. (1991a). Understanding Customer Expectations of Services. Sloan Management Review, 32, 39-48.

Parasuraman, A., Berry, L.L. og Zeithaml, V.A. (1991b). Perceived Service Quality as a Customer-Based Performance: An Empirical Examination of Organizational Barriers Using an Extended Service Quality Model. Human Resource Management, 30, 335-364.

Parasuraman, A., Berry, L.L. og Zeithaml, V.A. (1994). Reassessment of Expectations as a Comparison Standard in Measuring Service Quality: Implications for Further Research. Journal of Marketing, 58, 111-124.

Parasuraman, A., Zeithaml, V.A. og Berry, L.L. (1988). SERVQUAL: A Multiple-Item Scale for Measuring Consumer Perceptions of Service Quality. Journal of Retailing, $64,12-40$. 
Rotondaro, R.G. (2002). Defining the Customer's Expectations in e-business. Industrial Management + Data Systems, 102, 476-482.

Solomon, M., Bamossy, G. og Askegaard, S. (2002). Consumer Behaviour. A European Perspective. Essex: Pearson Education Ltd.

Teas, R.K. (1993). Expectations, Performance Evaluation and Consumers' Perception of Quality. Journal of Marketing, 57, 18-34.

Walker, J. og Baker, J. (2000). An exploratory study of a multy-expectation framework for services. Journal of Services Marketing, 14, 411-431.

Williams, J. (2002). Student Satisfaction: A British model of effective use of student feedback in quality assurance and enhancement. $14^{\text {th }}$ International Conference on Assessment and Quality in Higher Education. Sótt 11. maí 2005 á www.uce.ac.uk/crq/presentations/vienna2002james.pdf.

Woodruff, R.B., Cadotte, E.R. og Jenkins, R.L. (1987). Expectations and Norms in Models of Customer Satisfaction. Journal of Marketing Research, 24, 305-315.

Zeithaml, V.A., Bitner, M.J. og Gremler, D.D. (2006). Services Marketing, Integrating Customer Focus Across the Firm. New York: McGraw-Hill.

Zeithaml, V.A. og Bitner, M.J. (2003). Services Marketing, Integrating Customer Focus Across the Firm. New York: McGraw-Hill Higher Education.

Zeithaml, V.A. og Bitner, M.J. (1996). Services Marketing. New York: McGraw-Hill.

Zeithaml, V.A., Berry, L.A. og Parasuraman, A (1993). The Nature and Determinants of Customer Expectations of Service. Journal of the Academi of Marketing Science, 21, 112.

Zeithaml, V.A., Parasuraman, A. og Berry, L.L. (1990). Delivering Quality Service: Balancing Customer Perception and Expectations. New York: Free Press.

Zinkham, G.M. (2001). Relationship Marketing: Theory and Implementation. Journal of Marketing, 5, 83-89.

Pórhallur Guðlaugsson og Valdimar Sigurðsson (2005) Rannsókn á viðhorfi og væntingum nýnema við Háskóla Íslands haustið 2004. Reykjavík: Háskóli Íslands. 